\title{
Trade Integration, Competition, and the Decline in Exchange-Rate Pass-Through
}

Christopher Gust, Sylvain Leduc, and Robert J. Vigfusson

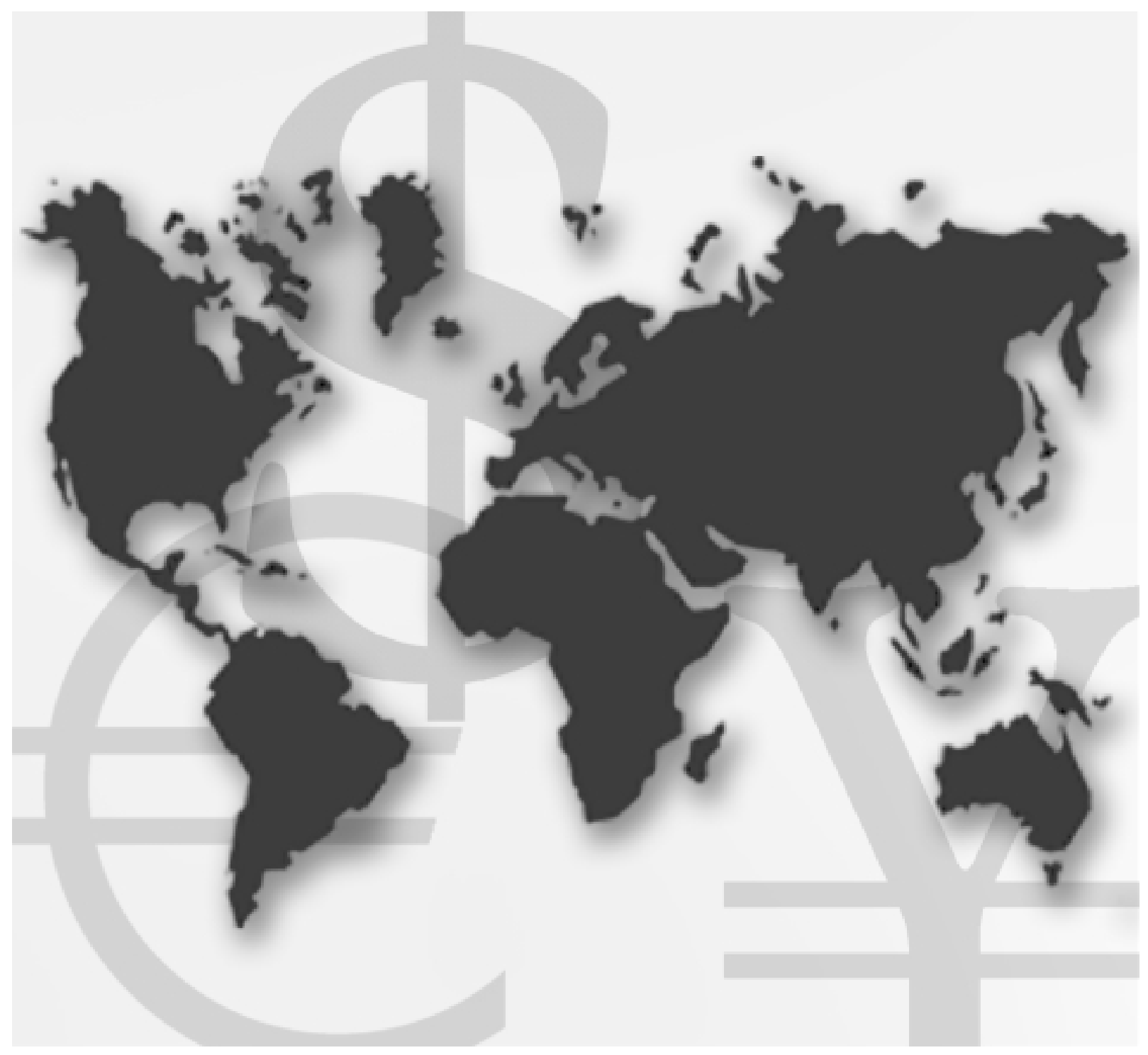

International Finance Discussion Papers

Board of Governors of the Federal Reserve System

Number 864

August 2006 
Board of Governors of the Federal Reserve System

International Finance Discussion Papers

Number 864

August 2006

Trade Integration, Competition, and the Decline in Exchange-Rate Pass-Through

Christopher Gust, Sylvain Leduc, and Robert J. Vigfusson

NOTE: International Finance Discussion Papers are preliminary materials circulated to stimulate discussion and critical comment. References in publications to International Finance Discussion Papers (other than an acknowledgment that the writer has had access to unpublished material) should be cleared with the author or authors. Recent IFDPs are available on the Web at www.federalreserve.gov/pubs/ifdp/. This paper can be downloaded without charge from Social Science Research Network electronic library at http://www.ssrn.com/. 



\title{
Trade Integration, Competition, and the Decline in Exchange-Rate Pass-Through*
}

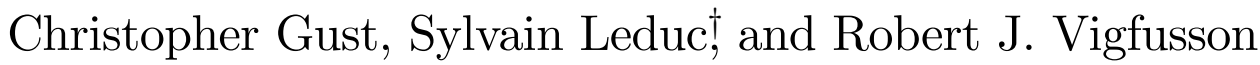 \\ Federal Reserve Board
}

August 2006

\begin{abstract}
Over the past twenty years, U.S. import prices have become less responsive to the exchange rate. We propose that a significant portion of this decline is a result of increased trade integration. To illustrate this effect, we develop an open economy DGE model in which trade occurs along both the intensive and extensive margins. The key element we introduce into this environment is strategic complementarity in price setting. As a result, a firm's pricing decision depends on the prices set by its competitors. This feature implies that a foreign exporter finds it optimal to vary its markup in response to shocks that change the exchange rate, insulating import prices from exchange rate movements. With increased trade integration, exporters have become more responsive to the prices of their competitors and this change in pricing behavior accounts for a significant portion of the observed decline in the sensitivity of U.S import prices to the exchange rate.
\end{abstract}

JEL classification: F15, F41

Keywords: Pass-through, trade integration, strategic complementarity

\footnotetext{
*We thank Jeannine Bailliu, Martin Bodenstein, Jeff Campbell, Luca Dedola, Joe Gagnon, Jordi Galí, Luca Guerrieri, and seminar participants at the Federal Reserve Board, Federal Reserve Bank of Chicago, Bank of Canada, and Université Laval for helpful comments. The views expressed in this paper are solely the responsibility of the authors and should not be interpreted as reflecting the views of the Board of Governors of the Federal Reserve System or of any other person associated with the Federal Reserve System.

${ }^{\dagger}$ Corresponding Author: Sylvain Leduc, Telephone 202-452-2399, Fax 202-736-5638. Email addresses: christopher.gust@frb.gov, sylvain.leduc@frb.gov, robert.vigfusson@frb.gov.
} 



\section{Introduction}

An important factor influencing trade balance dynamics and the transmission of business cycle across countries is the responsiveness of import prices to exchange-rate movements. To the extent that exchange-rate pass-through to import prices is low, currency fluctuations will be accompanied by small changes in trade prices and quantities, muting the international spillover effects of shocks on domestic activity and prices. As a consequence, exchange-rate pass-through is particularly relevant for monetary policymakers interested in maintaining price stability. ${ }^{1}$ Furthermore, in a low pass-through environment, the effects of a dollar depreciation on the trade balance may be limited, which has important ramifications for the ongoing debate concerning how adjustment of the current U.S. trade deficit may be resolved. ${ }^{2}$

What is the extent of exchange-rate pass-through (pass-through herein) to import prices? Consistent with the evidence surveyed in Goldberg and Knetter (1997), our estimate of passthrough for the 1980s is roughly 55 percent for the United States. This estimate implies that, following a 10 percent depreciation of the dollar, a foreign exporter selling to the U.S. market would raise its price in the United States by 5.5 percent. In the 1990s, however, we document that there has been a considerable decline in pass-through, as fluctuations in import prices have moderated substantially relative to exchange rate fluctuations. ${ }^{3}$

In this paper, we develop a novel approach that links this fall in pass-through to an increase in trade integration spurred by lower tariffs, transport costs, and changes in relative productivities across countries. Following the recent international trade literature, we build a real, open economy model with endogenous entry and exit of exporters so that trade occurs along both the intensive and extensive margins. ${ }^{4}$ We study incomplete pass-through building on the work of Kimball (1995) and more recently, Dotsey and King (2005). These papers allow for strategic complementarity in price setting using demand curves for which (the absolute value) of the demand elasticity is increasing in a firm's price relative to the price of its competitors. ${ }^{5}$

\footnotetext{
${ }^{1}$ See, for example, Corsetti and Pesenti (2005) and Devereux and Engel (2003), who show how optimal monetary policy depends on the extent of exchange-rate pass-through.

${ }^{2}$ See Gust and Sheets (2006) for a discussion of how trade balance dynamics change in a low pass-through environment.

${ }^{3}$ Our empirical evidence is in line with the work of Olivei (2002) and Marazzi, Sheets, and Vigfusson (2005) for the United States. Ihrig, Marazzi, and Rothenberg (2006) also document a fall in pass-through in other G-7 economies, and Otani, Shiratsuka, and Shirota (2003) find a decline in exchange rate pass-through in Japan.

${ }^{4}$ As in Melitz (2003), Ghironi and Melitz (2005), Bergin and Glick (2005), and Alessandria and Choi (2006), we postulate that monopolistically competitive firms face fixed costs of exporting and only a fraction of firms choose to export.

${ }^{5}$ We follow Woodford (2003) and define pricing decisions to be strategic complements if an increase in the prices charged for other goods increases a firm's own optimal price. For a similar approach to modelling the
} 
This feature implies that a firm's pricing decision depends not only on its marginal cost but also on the prices of its competitors. Because a foreign exporter does not want its price to deviate too far from its competitors, it is optimal for the exporter to increase its markup in response to a dollar appreciation that lowers its costs in dollars. Accordingly, pass-through of exchange-rate changes to import prices is incomplete in an environment with strategic complementarity in price setting.

It is well known that models with strategic complementarity have incomplete passthrough. Our main contribution is to show that, in a model with strategic complementarity, factors that lead to greater trade integration may reduce pass-through. In our model, lower per-unit trade costs or higher productivity improve the relative competitiveness of a foreign exporter in the domestic market - allowing the foreign firm to increase its relative markup over costs. ${ }^{6}$ With strategic complementarity, the foreign exporter's price becomes more responsive to the prices of its competitors as its markup increases, and the firm finds it optimal to vary its markup more and its price less in response to an exchange rate movement, i.e., lower passthrough. In our model, strategic complementarity thus induces an exporter to set a relatively high and variable markup when its costs are lower than its competitors and a low and unresponsive markup when its costs are relatively high. We show that this mechanism has a significant impact on the pricing behavior of exporting firms. In our benchmark calibration, lower trade costs and higher foreign productivity account for about one third of the observed decline in pass-through since the early 1990s.

We also assess the importance of exporters' entry decisions for trade integration and exchange-rate pass-through. With endogenous entry, the model is better able to account for the rise in the U.S. import share over the last 25 years. Similar to Dornbusch (1987), the entry of foreign exporters, other things equal, leads to a rise in exchange-rate pass-through. However, we show that following a reduction in the cost of exporting the effects of markups adjustments that arise only along the intensive margin largely dominate the impact of entry on pass-through.

Another implication of our model is that factors that increase trade integration induce an economy to become more competitive. Because lower trade costs reduce the prices of foreign exports relative to domestic producers, domestic producers lose market share. Strategic complementarity in price setting induces these producers to reduce their markups in response

strategic complementarity in an open economy, see Bergin and Feenstra (2001). For a game-theoretic approach, see, for example, Atkeson and Burstein (2005), Bernard, Eaton, Jensen, and Kortum (2003), or Bodnar, Dumas, and Marston (2002).

${ }^{6}$ In contrast, markups would be constant for a CES demand curves where there is no strategic complementarity. 
to the decline in the prices of foreign exporters. ${ }^{7}$ The approach developed in this paper is thus in line with the view that trade integration has reduced the market power of U.S. producers and squeezed their profit margins.

Finally, to support our theoretical findings, we provide empirical evidence linking the fall in pass-through to lower trade costs. Using industry specific measures of pass-through and trade costs, we show that industries in which the decline in trade costs has been relatively large have also experienced relatively large declines in pass-through.

The paper is organized as follows. The next section presents evidence on the decline in pass-through in the United States, while Section 3 describes the time-series properties of trade costs and documents changes in productivities in different regions of the world. The model is described in Section 4, and we relate our statistical measure of pass-through to the model in Section 5. Section 6 discusses the model's calibration and our results are presented in Section 7. The last section concludes.

\section{U.S. Import Prices and the Real Exchange Rate}

We first examine the statistical relationship between import prices and the exchange rate and document the increasing disconnect between these variables.

In our analysis, we focus on imports that are included in the end-use categories of automotive products, consumer goods, and capital goods, excluding computers and semiconductors. We will refer to these categories as finished goods, which account for 45 percent of the nominal value of total imports since 1987.

We concentrate on this more narrowly defined measure of import prices for two reasons. First, we exclude import prices of services, computers, and semiconductors because of concerns about price measurement. Prices for services are notoriously hard to measure. In addition, over time, different kinds of services have been added to the measured series and thus their composition is particularly unstable. We also exclude computers and semiconductors since their hedonic prices are heavily influenced by rapid increases in technology.

Second, our preferred measure excludes import prices of foods, feeds, beverages, and industrial supplies, because we view our model as less applicable to these categories. ${ }^{8}$ In par- $^{-}$ ticular, we model the determination of import prices as arising from the decisions of firms that

\footnotetext{
7 This result is consistent with the evidence in Chen, Imbs, and Scott (2004) who estimate that markups have fallen in the European Union since 1990.

8 Industrial supplies include oil, natural gas, non-fuel primary commodities, such as copper, and more processed items, such as chemicals.
} 
are monopolistic competitors and have the ability to price discriminate across countries. In the context of our model, excluding these goods is sensible since many of these goods are homogeneous and are traded on organized exchanges, so that the extent of monopolistic behavior and price discrimination is limited.

We argue that the decline in pass-through can be understood using a real model and thus focus on real import prices and real exchange rates. Accordingly, we define the real price of imports as the ratio of the finished goods import price deflator to the U.S. CPI deflator. Henceforth we will refer to our relative price index of finished goods as the relative price of imports. For our measure of the real exchange rate, we use the Federal Reserve's real effective exchange rate, which is constructed from data on nominal exchange rates and consumer price indices for 39 countries.

The top panel of Figure 1 plots the relative price of imports and the real exchange rate (as the inverse of the Federal Reserve's real effective exchange rate) so that a rise in the real exchange rate denotes a real depreciation of the dollar. Our relative import price index (the solid green line) has fallen over time, reflecting in part that goods' prices have declined relative to the prices of services. To abstract from this trend, the dashed orange line shows the ratio of the price of imported goods to a consumption price index that excludes services. ${ }^{9}$ Using this series, it is apparent that real import prices and the real exchange rate in the 1980-2004 period have tended to move closely together, although movements in import prices tend to be dampened relative to the exchange rate. This series also suggests that in the 1990s movements in relative import prices have become more disconnected from movements in real exchange rates. Import prices rose in the 1970s with the dollar's depreciation and also rose sharply in the late 1980s with the large dollar depreciation beginning in 1985. In contrast, import price movements have been much more subdued in the 1990s: even though the dollar depreciated in the early 1990s and then appreciated in the latter half of the decade, import prices remained relatively unchanged.

The same basic pattern emerges when we remove the trends in relative prices by examining the series in log-differences. The middle panel of Figure 1 plots the relative price of imports (the solid green line) and the real exchange rate (the dashed orange line) after log-differencing these series. The relative import price, though less volatile than the real exchange rate, is highly correlated with it. Moreover, import price volatility appears to have moderated relative to exchange rate volatility since the late 1980s.

\footnotetext{
${ }^{9}$ We use NIPA data to apply standard chain-aggregation routines to construct both our deflator for imported finished goods and our deflator of U.S. consumption goods that excludes services.
} 
Table 1 summarizes these findings by comparing the volatility and correlation of the relative import price and the real exchange rate over different subsamples. The top panel shows the results for the data in differences and the bottom panel for HP-filtered data. Both the HP-filtered and differenced data show a marked decline in the ratio of the standard deviation of import prices, $\sigma_{p_{m}}$, to the standard deviation of the exchange rate, $\sigma_{q}$, in the latter half of our sample. The correlation of the relative import price with the real exchange rate has declined noticeably as well.

Another important statistic summarizing the relationship between these two series is:

$$
\beta_{p_{m}, q}=\frac{\operatorname{cov}\left(p_{m}, q\right)}{\sigma_{q}^{2}}=\operatorname{corr}\left(p_{m}, q\right) \frac{\sigma_{p_{m}}}{\sigma_{q}}
$$

where $p_{m}$ denotes the relative price of imports and $q$ denotes the real exchange rate. This statistic takes into account the correlation between the two series as well as their relative volatility and can be derived as the estimate from a univariate least squares regression of the real exchange rate on the relative import price. As shown in Table 1 , our estimate of $\beta_{p_{m}, q}$ has declined in the 1990s, reflecting both the decline in the relative volatility of import prices and the lower correlation between the two series. Further evidence of the increasing disconnect between these variable is shown in the bottom panel of Figure 1 which plots estimates of $\beta_{p_{m}, q}$ for the log-differenced data based on 10-year, rolling windows (The line with stars indicates the point estimate and the shaded region denotes the 95 percent confidence region.) There is a gradual decline in $\beta_{p_{m}, q}$ beginning in the mid-1980s.

We view the decline in $\beta_{p_{m}, q}$ as a useful way of summarizing the increasing disconnect between the relative import price and the real exchange rate. Our summary statistic, $\beta_{p_{m}, q}$, is closely related to estimates of pass-through in empirical studies. One notable difference is that these studies typically estimate a specification for import prices with the exchange rate controlling for a number of other factors influencing import prices. A recent paper that follows this approach is Marazzi, Sheets, and Vigfusson (2005), who argue that pass-through of exchange rate changes to import prices has fallen from about 0.5 in the 1980 s to a current estimate of 0.2 . One reason we choose to use the statistic $\beta_{p_{m}, q}$ is that it eases comparisons between the model and the data. However, we note that we get comparable estimates to Marazzi, Sheets, and Vigfusson (2005) regarding the change in the relationship between import prices and the exchange rate. ${ }^{10}$

\footnotetext{
10 When estimating pass-through, Marazzi, Sheets, and Vigfusson (2005) control for movements in marginal costs using foreign CPIs and commodity prices. The results are also similar if different control variables are
} 
Examining more dissaggregated data, we also document that the decline in pass-through is broad-based. For industry $i$, Figure 2 reports our summary statistics, $\beta_{p_{m}, q}^{i}$, using data in log-differences on prices for each of 40 finished goods industries (a mixture of two- and threedigit SITC industries) and our real exchange rate measure defined earlier. (See the appendix for a description of these industries.) This statistic is computed for two sample periods: preand post-1990. As can be seen in Figure 2, most industries have experienced a sizeable decline in $\beta_{p_{m}, q}^{i}$. Taking a simple average across industries, the mean value of $\beta_{p_{m}, q}^{i}$ declined almost 40 percentage points, from an industry-average value of 0.61 pre-1990 to a value of 0.22 post-1990.

Overall, the evidence suggests that there has been an increasing disconnect between the price of imported finished goods and the exchange rate. ${ }^{11}$

\section{Trade Costs and Productivity}

In this section, we address the time series evidence regarding whether tariffs and transport costs have fallen over time as well as discuss the behavior for other forms of trade costs. We also examine the data on changes in the relative productivity of the United States vis-à-vis its trading partners.

Barriers to international trade take many forms, some less tangible than others. Typically, tariffs and transport costs come to mind as factors impeding the flow of goods across countries. However, international trade can also be hindered by the presence of legal and regulatory costs, distribution costs, and institutional and cultural barriers. Although tariffs and transport costs make up only a fraction of overall trade costs, they remain an important factor underlying the movement towards greater trade integration. For instance, Baier and Bergstrand (2001) find that the decline in tariff rates and transport costs played an important role in post-World-War-II expansion in international trade for OECD countries. ${ }^{12}$

Data on tariffs and transport costs support the notion that trade costs have been falling over time. For the United States, detailed information on tariffs and transport costs are available

used. For instance, pass-through declines to the same extent when unit labor costs and domestic output are respectively used to control for changes in marginal costs and import demand, as in Campa and Goldberg (2004).

11 This decline in pass-through is most evident for finished goods. The decline in pass-through for total imports is smaller and less precisely estimated.

12 The fact that tariff and transport costs have been declining throughout the post-war period yields the implication in our model that, other things equal, exchange-rate pass-through to import prices should have declined throughout the post-war period. Unfortunately, our measure of import prices for finished goods industries does not extend back far enough to investigate this possibility. 
from Feenstra (1996) and Feenstra, Romalis, and Schott (2002) who have compiled productlevel import data. Using this data, we compute tariffs and transport costs for finished-goods industries from 1980 to 2001. For each available industry, we measure trade costs as the sum of transport costs and tariffs and compute an industry-weighted average trade cost measure. (See the appendix for the details of these calculations.)

Figure 3 reports that, over our sample period, the average trade cost across industries fell from 11.1 percent of the custom value of the goods in 1980 to 5.2 percent in 2001. The figure also decomposes our average trade cost measure into its tariffs and transport costs components. It shows that transport costs have declined somewhat since 1980 but that the fall in trade costs has been driven mostly by a reduction in tariffs.

Although tariffs and transport costs have the advantage of being relatively easier to quantify, it is more difficult to measure precisely other forms of trade costs, since they are often not directly observable. As a result, researchers infer these costs by estimating gravity models of international trade. This literature finds mixed evidence regarding a possible decline in overall trade costs. ${ }^{13}$ As a result, we take a conservative approach and focus only on the evidence regarding transport costs and tariffs.

Since trade integration can also be triggered by improved productivity of exporting firms, we document changes in relative productivity across countries. The top panel of Figure 4 displays the annualized percentage change in GDP per employee for the United States ('US'), its foreign counterpart ('ROW'), and other regions around the world for the 1980-2003 period. ${ }^{14}$ These indices are constructed using data on GDP per employee, and the ROW index is based on data for OECD and major developing countries. Growth in GDP per employee outside the United States outpaced U.S. growth largely due to faster productivity growth in developing Asia ('DA'), which includes a number of rapidly-developing countries such as China and South Korea. Productivity growth in Europe ('EU') was roughly on par with growth in the United States, while Japanese ('JA') productivity growth was somewhat faster than in the United States, despite a marked deceleration in Japanese productivity in the 1990s.

With foreign labor productivity growth higher than U.S. productivity growth over the last two decades, there has been considerable convergence of foreign productivity to the level

\footnotetext{
${ }^{13}$ Using different datasets and methodologies, Rauch (1999), Coe, Subramanian, Tamirisa, and Bhavnani (2002), and Brun, Carrere, Guillaumont, and de Melo (2005) find that trade costs have fallen continuously since the 1970s. On the other hand, Frankel (1997) and Berthelon and Freund (2004) find no evidence of a significant decline in trade costs.

${ }^{14}$ Although we would prefer a more disaggregated measure, we focus on productivity at the aggregate level due to data limitations for developing countries.
} 
of U.S. productivity. The bottom panel of Figure 4 shows that GDP per employee outside the United States roughly doubled over the 1980-2003 period, while U.S. GDP per employee rose about 40 percent over this period. As a consequence, the level of foreign productivity has increased by 40 percent relative to U.S. productivity over the past twenty-five years.

\section{The Model}

Our model consists of a home and a foreign economy. These two economies have isomorphic structures so in our exposition we focus on describing only the domestic economy. The domestic economy consists of two types of agents: households and firms. Households have utility that depends on the consumption of both domestically-produced goods and imported goods. These goods are purchased from monopolistically competitive firms, who set prices flexibly each period. While the range of goods produced by these firms is exogenously given, the fraction of firms that export is determined endogenously. In particular, because a firm must pay both a fixed and variable cost to export its good, it may choose to sell its good only in the domestic economy. The key element we introduce into this environment is that a firm's demand curve has a non-constant elasticity so that exchange-rate pass-through to import prices may be incomplete.

We abstract from other features such as sticky prices and distribution costs that give rise to incomplete pass-through. We view our approach as largely complementary to these alternatives. For instance, Bergin and Feenstra (2001) have shown that the interaction of demand curves with non-constant elasticities and sticky prices denominated in local currency is helpful in accounting not only for incomplete pass-through but also for the observed volatility and persistence of the exchange rate. Our approach also would complement models that include a distribution sector for traded goods such as Corsetti and Dedola (2005) and Corsetti, Dedola, and Leduc (2005) and results in incomplete pass-through to import prices at both the retail level and the point of entry. Although nominal rigidities or distribution costs imply incomplete pass-through, it is more difficult to account for the decline in pass-through based exclusively on these features. For simplicity and to emphasize the role of trade integration and strategic complementarity in price setting, we therefore choose not to incorporate these elements into our analysis. 


\subsection{Households}

The utility function of the representative household in the home country is

$$
E_{t} \sum_{j=0}^{\infty} \beta^{j}\left\{\log \left(C_{t+j}\right)-\chi_{0} \frac{L_{t+j}^{1+\chi}}{1+\chi}\right\}
$$

where the discount factor $\beta$ satisfies $0<\beta<1$ and $E_{t}$ is the expectation operator conditional on information available at time $t$. The period utility function depends on consumption $C_{t}$ and labor $L_{t}$. A household also purchases state-contingent assets $b_{t+1}$ that are traded internationally so that asset markets are complete.

Household's receive income from working and an aliquot share of profits of all the domestic firms, $\Omega_{t}$. In choosing its contingency plans for $C_{t}, L_{t}, b_{t+1}$, a household takes into account its budget constraint at each date:

$$
C_{t}+\int_{s} p_{b t, t+1} b_{t+1}-b_{t}=w_{t} L_{t}+\Omega_{t}
$$

In equation (3), $w_{t}=\frac{W_{t}}{P_{t}}$ is household's real wage and $p_{b t, t+1}$ denotes the price of an asset that pays one unit of the domestic consumption good in a particular state of nature at date $t+1$. (For convenience, we have suppressed that variables depend on the state of nature.).

\subsection{Demand Aggregator}

There is a continuum of goods indexed by $i \in[0,1]$ produced in each economy. While a domestic household purchases all of the domestically-produced goods, there are only $i \in\left[0, \omega_{t}^{*}\right]$ that are available for imports, where $\omega_{t}^{*}$ denotes the endogenously determined fraction of traded foreign goods. A household chooses domestically-produced goods, $C_{d t}(i)$, and imported goods, $C_{m t}(i)$, to minimize their total expenditures:

$$
\left[\int_{0}^{1} P_{d t}(i) C_{d t}(i) d i+\int_{0}^{\omega_{t}^{*}} P_{m t}(i) C_{m t}(i) d i\right]
$$

subject to $D\left(\frac{C_{d t}(i)}{C_{t}}, \frac{C_{m t}(i)}{C_{t}}\right)=1$. In minimizing its expenditures, a household takes the prices of the domestic, $P_{d t}(i)$, and imported goods, $P_{m t}(i)$, as given. (For convenience, we denote these prices in nominal terms, although prices are flexible in the model and we solve only for real variables.) In our model, there are no distribution services required to sell the imported goods 
to households. Accordingly, $P_{m t}(i)$ denotes both the retail import price for good $i$ and price charged at the point of entry.

The function, $D\left(\frac{C_{d t}(i)}{C_{t}}, \frac{C_{m t}(i)}{C_{t}}\right)$, is a household's demand aggregator for producing a unit of $C_{t}$ and is defined by:

$$
D\left(\frac{C_{d t}(i)}{C_{t}}, \frac{C_{m t}(i)}{C_{t}}\right)=\left[\frac{1}{1+\omega_{t}^{*}} V_{d t}^{\frac{1}{\rho}}+\frac{\omega_{t}^{*}}{1+\omega_{t}^{*}} V_{m t}^{\frac{1}{\rho}}\right]^{\rho}-\frac{1}{(1+\eta) \gamma}+1,
$$

In this expression, $V_{d t}$ is an aggregator for domestic goods given by:

$$
V_{d t}=\int_{0}^{1} \frac{1}{\left(1+\omega_{t}^{*}\right)(1+\eta) \gamma}\left[\left(1+\omega_{t}^{*}\right)(1+\eta) \frac{C_{d t}(i)}{C_{t}}-\eta\right]^{\gamma} d i,
$$

and $V_{m t}$ is an aggregator for imported goods given by:

$$
V_{m t}=\frac{1}{\omega_{t}^{*}} \int_{0}^{\omega_{t}^{*}} \frac{1}{\left(1+\omega_{t}^{*}\right)(1+\eta) \gamma}\left[\left(1+\omega_{t}^{*}\right)(1+\eta) \frac{C_{m t}(i)}{C_{t}}-\eta\right]^{\gamma} d i .
$$

Our demand aggregator adapts the one discussed in Dotsey and King (2005) to an international environment. It shares the central feature that the elasticity of demand is nonconstant (NCES) with $\eta \neq 0$, and the (absolute value of the) demand elasticity can be expressed as an increasing function of a firm's relative price when $\eta<0 .{ }^{15}$ This feature has proven useful in the sticky price literature, because it helps mitigate a firm's incentive to raise its price after an expansionary monetary shock in the context of a model in which other firms have already preset their prices. It is also consistent with the evidence that firms tend to change their prices more in response to cost increases than decreases (see, for instance, Peltzman (2000)). Another important implication of this aggregator, discussed below, is that exchange-rate pass-through to import prices will be incomplete when the elasticity of demand is increasing in a firm's relative price.

Expenditure minimization by a domestic household implies that the demand curve for

${ }^{15}$ When $\eta=0$, our demand aggregator can be thought of as the combination of a Dixit-Stiglitz and Armington aggregator. To see this, note that in this case we can rewrite our aggregator as:

$$
C_{t}=\left(1+\omega_{t}^{*}\right)\left[\frac{1}{1+\omega_{t}^{*}} C_{d t}^{\frac{\gamma}{\rho}}+\frac{\omega_{t}^{*}}{1+\omega_{t}^{*}} C_{m t}^{\frac{\gamma}{\rho}}\right]^{\frac{\rho}{\gamma}}
$$

where $C_{d t}=\left(\int_{0}^{1} C_{d t}(i)^{\gamma} d i\right)^{\frac{1}{\gamma}}$ and $C_{m t}=\left(\frac{1}{\omega_{t}^{*}} \int_{0}^{\omega_{t}^{*}} C_{m t}(i)^{\gamma} d i\right)^{\frac{1}{\gamma}}$. Our specification of the demand aggregator also rules out the "love of variety" effect. 
an imported good is given by:

$$
\frac{C_{m t}(i)}{C_{t}}=\frac{1}{1+\omega_{t}^{*}}\left[\frac{1}{1+\eta}\left(\frac{P_{m t}(i)}{\Gamma_{t}}\right)^{\frac{1}{\gamma-1}}\left(\frac{P_{m t}}{\Gamma_{t}}\right)^{\frac{\gamma}{\gamma-\rho} \frac{\rho-1}{\gamma-1}}+\frac{\eta}{1+\eta}\right] .
$$

In the above, $\Gamma_{t}$ is a price index consisting of the prices of a firm's competitors defined as:

$$
\Gamma_{t}=\left[\left(\frac{1}{1+\omega_{t}^{*}}\right) P_{d t}^{\frac{\gamma}{\gamma-\rho}}+\left(\frac{\omega_{t}^{*}}{1+\omega_{t}^{*}}\right) P_{m t}^{\frac{\gamma}{\gamma-\rho}}\right]^{\frac{\gamma-\rho}{\gamma}},
$$

and $P_{d t}$ and $P_{m t}$ are indices of domestic and import prices defined as:

$$
\begin{aligned}
& P_{d t}=\left(\int_{0}^{1} P_{d t}(i)^{\frac{\gamma}{\gamma-1}} d i\right)^{\frac{\gamma-1}{\gamma}}, \\
& P_{m t}=\left(\frac{1}{\omega_{t}^{*}} \int_{0}^{\omega_{t}^{*}} P_{m t}(i)^{\frac{\gamma}{\gamma-1}} d i\right)^{\frac{\gamma-1}{\gamma}} .
\end{aligned}
$$

Expenditure minimization also implies an analagous expression for the demand curve of domestic good $i$, which depends on prices, $P_{d t}(i), P_{d t}$, and $\Gamma_{t}$.

A property of these demand curves is that the elasticity of substitution between a home and foreign good can differ from the demand elasticity for two home goods. This separate elasticity for goods occurs when $\rho \neq 1$, which gives the model more flexibility to match estimates of the elasticity of substitution between home and foreign tradeables as well as estimates of economy-wide markups. More importantly, when $\eta \neq 0$, the demand curve has an additive linear term, which implies that the elasticity of demand depends on the price of good $i$ relative to other prices. It is this feature that helps give rise to incomplete pass-through to import prices and implies that pass-through depends on the economy's structure including the underlying shocks.

The aggregate consumer price level is given by

$$
P_{t}=\frac{1}{1+\eta} \Gamma_{t}+\frac{\eta}{1+\eta}\left[\frac{1}{1+\omega_{t}^{*}} \int_{0}^{1} P_{d t}(i) d i+\frac{1}{1+\omega_{t}^{*}} \int_{0}^{\omega_{t}^{*}} P_{m t}(i) d i\right] .
$$

From this expression, it is clear that the consumer price level is equal to the competitive pricing bundle, $\Gamma_{t}$, when $\eta=0$. In general, the consumer price level is the sum of $\Gamma_{t}$ with a linear aggregator of prices for individual goods. ${ }^{16}$

\footnotetext{
${ }^{16}$ The consumer price level can be derived from equating equation (4) to $P_{t} C_{t}$ and substituting in the relative
} 


\subsection{Firms}

The production function for firm $i$ is linear in labor so that

$$
Y_{t}(i)=Z_{t} L_{t}(i)
$$

In the above, $Z_{t}$ is an aggregate, iid technology shock that affects the production function for all firms in the home country. A firm hires labor in a competitive market in which labor is completely mobile within a country but immobile across countries. Marginal cost is therefore the same for all firms in the home country so that real marginal cost of firm $i$ is given by $\frac{w_{t}}{Z_{t}}$.

Firms in each country are monopolistically competitive and each firm sells its good to households located in its country. Profit maximization implies that a firm chooses to set its price as a markup over marginal cost. As a result, the price of good $i$ in the domestic market satisfies:

$$
\frac{P_{d t}(i)}{P_{t}}=\mu_{d t}(i) \frac{w_{t}}{Z_{t}}, \quad i \in[0,1]
$$

with $\mu_{d t}(i) \geq 1$. The markup $\mu_{d t}(i)$ can be expressed as:

$$
\mu_{d t}(i)=\mu_{d t}=\left[1-\frac{1}{\left|\epsilon_{d t}\right|}\right]^{-1}=\left[\gamma+\eta(\gamma-1)\left(\frac{P_{d t}}{\Gamma_{t}}\right)^{\frac{\rho}{\rho-\gamma}}\right]^{-1}
$$

where $\left|\epsilon_{d t}\right|$, is the absolute value of the elasticity of a domestic good given by:

$$
\epsilon_{d t}=\left[(\gamma-1)\left(1+\eta\left(\frac{P_{d t}}{\Gamma_{t}}\right)^{\frac{\rho}{\rho-\gamma}}\right)\right]^{-1}
$$

In the above, we have dropped the index $i$, since we restrict our attention to a symmetric equilibrium in which all firms set the same price in the domestic market (i.e., $P_{d t}(i)=P_{d t}$, $\epsilon_{d t}(i)=\epsilon_{d t}$, and $\mu_{d t}(i)=\mu_{d t}$. $)$

Equation (15) shows that a firm's markup depends on the price it sets relative to its competitors price $\Gamma_{t}$. When the (absolute value of) the demand elasticity is increasing in $\frac{P_{d t}}{\Gamma_{t}}$, the markup will be a decreasing function of this relative price. Consequently, a firm will respond to a fall in the price of its competitors by lowering its markup and price. A firm finds it desirable to do so, because otherwise it will experience a relatively large fall in its market share.

demand curves. The price $\Gamma_{t}$ can be derived from substituting the relative demand curves into equation (5). 
An important exception to this pricing behavior is the CES demand curve in which $\eta=0$. In this case, a firm's markup does not depend on the relative price of its competitors.

We view our setup with variable markups as a tractable way to capture the strategic complementarity amongst price-setting firms. Although we do not explicitly model strategic behavior using a game-theoretic framework, our setup has similar implications to those of Bodnar, Dumas, and Marston (2002), Bernard, Eaton, Jensen, and Kortum (2003), and Atkeson and Burstein (2005) who model the strategic complementarity that arises between firms through Cournot or Bertrand competition. These alternative setups, like ours, give rise to a markup that is increasing in a firm's market share or decreasing in its price relative to those of its competitors.

Following Melitz (2003), Ghironi and Melitz (2005) and Bergin and Glick (2005), we allow for the endogenous entry and exit of firms into the export market. In particular, we assume that each period a firm faces a fixed and per-unit export cost and decides whether to export or not. Unlike these previous papers, which allow productivity to vary with a good's type, we assume that the fixed cost varies with the variety of the good. ${ }^{17}$ In particular, we assume that the fixed cost is given by:

$$
f_{x}(i)=\frac{f_{x}}{1-\alpha_{x} i}, \quad \alpha_{x} \geq 0
$$

and is paid in units of labor. We view this fixed cost as reflecting the cost to a firm of making consumers aware of its product, setting up a distribution system, and understanding the legal and regulatory environment of a foreign market. It seems reasonable to assume that these costs differ depending on the type of good.

Since an exporter must make its entry decision before the realization of shocks in period $t$, a firm will choose to export if its expected profits from exporting (appropriately weighted) exceed its fixed cost:

$$
E_{t-1}\left[p_{b t-1, t}\left(\pi_{x t}(i)-f_{x}(i) w_{t}\right)\right]>0,
$$

17 In our environment with variable markups, heterogeneity in the technologies of firms would considerably complicate the analysis, since computing aggregate prices and quantities would involve accounting for a distribution of markups. In contrast, because the fixed cost does not affect a firm's marginal pricing condition, we can still analyze a symmetric equilibrium in which all firms who decide to export choose the same price and markup. 
where exporter $i$ 's per-unit profits in the foreign market are given by:

$$
\pi_{x t}(i)=\left(q_{t} \frac{P_{m t}^{*}(i)}{P_{t}^{*}}-\frac{D_{t} w_{t}}{Z_{t}}\right) C_{m t}^{*}(i)
$$

In the above, $q_{t}$ is the real exchange rate expressed in units of the home consumption bundle per units of foreign consumption, $P_{m t}^{*}(i)$ is the nominal price of home good $i$ denominated in foreign currency, and $C_{m t}^{*}(i)$ is the demand for home good $i$ by foreign households. (We use a star to denote foreign variables.) Also, $D_{t}$ is an iceberg shipping cost which we assume to be a stochastic iid process. ${ }^{18}$ Finally, our functional form for the fixed cost implies that only firms on the interval $i \in\left[0, \omega_{t}\right]$ will export their good where the marginal good $\omega_{t}$ satisfies equation (18) as an equality.

Similar to a firm's pricing decision in the domestic market, profit maximization implies that a firm chooses its export price as a markup over marginal cost:

$$
q_{t} \frac{P_{m t}^{*}(i)}{P_{t}^{*}}=\mu_{m t}^{*}(i) \frac{D_{t} w_{t}}{Z_{t}}, \quad i \in\left[0, \omega_{t}\right]
$$

In a symmetric equilibrium, all exporting firms will choose the same price and markup (i.e., $P_{m t}^{*}(i)=P_{m t}^{*}$ and $\left.\mu_{m t}^{*}(i)=\mu_{m t}^{*}\right)$. An exporter's markup is given by:

$$
\mu_{m t}^{*}(i)=\mu_{m t}^{*}=\left[1-\frac{1}{\left|\epsilon_{m t}^{*}\right|}\right]^{-1}=\left[\gamma+\eta(\gamma-1)\left(\frac{P_{m t}^{*}}{\Gamma_{t}^{*}}\right)^{\frac{\rho}{\rho-\gamma}}\right]^{-1},
$$

where $\left|\epsilon_{m t}^{*}\right|$ is the absolute value of the elasticity of a domestic good in the foreign market.

Comparing equations (14) and (20), we note that the law of one price (i.e., $\frac{P_{m t}^{*}(i)}{P_{t}^{*}} q_{t}=\frac{P_{d t}(i)}{P_{t}}$ ) will not hold when $D_{t}>1$. In addition, because the demand elasticity can differ across markets (i.e., $\epsilon_{d t} \neq \epsilon_{m t}^{*}$ ), a firm will optimally choose to price discriminate. It will be able to do so, if the difference between a firm's price in the two markets (expressed in the same currency unit) is less than the cost of shipping the good:

$$
\frac{D_{t} P_{d t}(i)}{P_{t}} \geq \frac{P_{m t}^{*}(i)}{P_{t}^{*}} q_{t} \text { and } \frac{P_{d t}(i)}{P_{t}} \leq \frac{D_{t}^{*} P_{m t}^{*}(i)}{P_{t}^{*}} q_{t}
$$

where $D_{t}^{*}$ denotes the per-unit cost of shipping a good from the foreign economy to the home

\footnotetext{
18 This assumption is not critical for our analysis. We assume that $D_{t}$ is stochastic mainly to illustrate how pass-through differs depending on the type of shock.
} 
economy. ${ }^{19}$ The first condition ensures that a foreign household can not buy the good for less in the domestic market inclusive of the cost of shipping the good. The second condition ensures that a domestic household can not buy the good for less abroad. Later, we verify that these conditions and their counterparts for the prices set by foreign firms are satisfied.

\subsection{Market Clearing}

The home economy's aggregate resource constraint can be written as:

$$
\int_{0}^{1} \frac{C_{d t}(i)}{Z_{t}} d i+\int_{0}^{\omega_{t}} \frac{D_{t} C_{m t}^{*}(i)}{Z_{t}} d i+\int_{0}^{\omega_{t}} f_{x}(i) d i=L_{t}
$$

Given that we focus on a symmetric equilibrium, we define aggregate output as $Y_{t}=Z_{t} L_{t}$. Finally, we note that the foreign economy has an isomorphic structure to the home economy and differs only in its level of trade costs and technology.

\section{Defining Pass-Through}

We consider two alternative definitions for import price pass-through. For the first, we define pass-through from the perspective of an individual exporter who views the exchange rate as exogenous. This definition considers how much an individual exporter changes his price in response to a one percent change in the exchange rate, holding constant the other factors a firm takes as given: its marginal cost and the prices of other firms. Letting $p_{m t}(i)=\frac{P_{m t}(i)}{P_{t}}$ and $\xi_{t}=\frac{\Gamma_{t}}{P_{t}}$ denote the relative price of exporter $i$ and the relative price of its competitors, respectively, a foreign exporter's pricing equation can be written as:

$$
p_{m t}(i)=\mu_{m t}(i) D_{t}^{*} \frac{w_{t}^{*}}{Z_{t}^{*}} q_{t}
$$

where $\mu_{m t}(i)$ is given by an analagous expression to equation (21). The direct effect of an exchange rate change on the price of foreign exporter $i$ is given by $\kappa_{m t}(i)=\frac{\partial p_{m t}(i)}{\partial q_{t}} \frac{q_{t}}{p_{m t}(i)}$ :

$$
\kappa_{m t}(i)=\frac{1}{1-\eta \mu_{m t}(i)\left(\frac{\rho(\gamma-1)}{\gamma-\rho}\right)\left(\frac{p_{m t}(i)}{\xi_{t}}\right)^{\frac{\rho}{\rho-\gamma}}}=\frac{1}{1+\left(\mu_{m t}(i)-1\right) \frac{\partial\left|\epsilon_{m t}(i)\right|}{\partial p_{m t}(i)} \frac{p_{m t}(i)}{\left|\epsilon_{m t}(i)\right|}} .
$$

\footnotetext{
19 Implicitly, we have assumed that a household faces the same per-unit cost of shipping the good as a firm and bears no fixed cost in transporting the good. To the extent that households also face fixed costs and larger per-unit shipping costs, their ability to engage in arbitrage is more limited than implied by equations (22).
} 
Because $\kappa_{m t}(i)$ measures only the direct effect of an exchange rate change on an exporter's price, we refer to it as the direct pass-through measure.

From the expression directly after the equality, we can see that if $\eta<0$ then direct pass-through will be incomplete. ${ }^{20}$ In this case, a one percent increase in $q_{t}$ drives up a foreign exporter's cost when denominated in dollars; however, a firm does not raise its price a full one percent because as the exporter's price rises relative to its competitors, it induces the exporter to accept a lower markup rather than give up market share.

Alternatively, the expression after the second equality in equation (25) indicates that direct pass-through depends on the level of the markup and the elasticity of the elasticity of demand, $\frac{\partial\left|\epsilon_{m t}(i)\right|}{\partial p_{m t}(i)} \frac{p_{m t}(i)}{\epsilon_{m t}(i) \mid}$. This expression is similar to the one derived by Eichenbaum and Fisher (2004) in a closed economy context. With $\eta<0$, the elasticity of the elasticity of demand is positive and as a result $\kappa_{m t}(i)<1$.

To facilitate comparisons of our model with the data, in addition to our direct passthrough measure, we also examine our model's implications for the second moment $\beta_{p_{m}, q}$ previously defined (in log-differences) as:

$$
\beta_{p_{m}, q}=\frac{\operatorname{cov}\left(\Delta p_{m t}, \Delta q_{t}\right)}{\operatorname{var}\left(\Delta q_{t}\right)} .
$$

The relationship between $\beta_{p_{m}, q}$ and $\kappa_{m t}(i)$ can be seen by log-linearizing equation (24) around the non-stochastic steady state to write a foreign exporter's pricing decision as:

$$
\hat{p}_{m t}=\kappa_{m}\left(\hat{D}_{t}^{*}+\hat{w}_{t}^{*}-\hat{Z}_{t}^{*}+\hat{q}_{t}\right)+\left(1-\kappa_{m}\right) \hat{\xi}_{t}
$$

The symbol "^) denotes the log-deviation of a variable from its steady state value and $\kappa_{m}=\kappa_{m}(i)$ evaluated at nonstochastic steady state. Using this equation, we can relate $\beta_{p_{m}, q}$ and $\kappa_{m}$ via:

$$
\beta_{p_{m}, q}=\kappa_{m}+\kappa_{m}\left[\frac{\operatorname{cov}\left(\Delta\left(\hat{w}_{t}^{*}-\hat{Z}_{t}^{*}\right), \Delta \hat{q}_{t}\right)}{\operatorname{var}\left(\Delta \hat{q}_{t}\right)}+\frac{\operatorname{cov}\left(\Delta \hat{D}_{t}^{*}, \Delta \hat{q}_{t}\right)}{\operatorname{var}\left(\Delta \hat{q}_{t}\right)}\right]+\left(1-\kappa_{m}\right)\left[\frac{\operatorname{cov}\left(\Delta \hat{\xi}_{t}, \Delta \hat{q}_{t}\right)}{\operatorname{var}\left(\Delta \hat{q}_{t}\right)}\right] .
$$

According to equation (28), the univariate regression statistic, $\beta_{p_{m}, q}$, is related to $\kappa_{m}$ except that $\beta_{p_{m}, q}$ takes into account any correlation of the real exchange rate with an exporter's costs and the pricing index of an exporter's competitors that occurs in general equilibrium. Thus, $\beta_{p_{m}, q}$ takes into account both direct and indirect effects of an exchange rate change on an exporter's price.

\footnotetext{
${ }^{20}$ With $\eta<0$, the demand curve is less convex than the CES case.
} 
In our analysis, we focus on comparing our model results to the data for $\beta_{p_{m}, q}$ rather than $\kappa_{m}$. This reflects that $\beta_{p_{m}, q}$ is a second moment that is easily measured in the data. In contrast, measuring $\kappa_{m}$ is complicated by finding good measures of marginal costs and the prices of a firm's competitors as well as correctly specifying the equations for estimating $\kappa_{m}$ and dealing with the endogeneity of the exchange rate and the prices of other firms.

\section{Calibration}

In order to investigate the role of trade costs and productivity differentials on pass-through, we log-linearize and solve the model around two different steady states. In the first, the home and foreign economies are identical, and both economies have relatively high trade costs. We call this our benchmark calibration. In the second, we lower trade costs as well as raise the level of foreign productivity, keeping the remaining parameters constant. ${ }^{21}$ We call this the 2004 calibration.

The value of $\eta$, which governs the curvature of the demand curve, is critical for our analysis. Faced with sparse independent evidence regarding this parameter, we calibrate it as a part of a simulated method of moments procedure. Specifically, we choose $\eta$ along with the standard deviations of the iid technology and trade cost shocks so that the model's implications for the volatility of output, the ratio of the volatility of relative import prices to the real exchange rate, and the correlation between relative import prices and the real exchange rate match those observed in the 1980-1989 period. In doing so, we constrain the standard deviation of the technology shocks and trade costs shocks to be the same in both countries (i.e., $\sigma_{z}=\sigma_{z}^{*}$ and $\left.\sigma_{D}=\sigma_{D^{*}}\right)$. By construction, our model matches the observed value of $\beta_{p_{m}, q}$ for the 1980s. With $\eta$ pinned down based on the pre-1990s data, we then examine the fall in $\beta_{p_{m}, q}$ arising from a fall in trade costs and a higher level of foreign productivity.

Tables 2 show our calibrated value of $\eta$ as well as the calibrated values of other important parameters of the model. We choose $\gamma$ to be consistent with an exporter's markup over marginal cost of around 20 percent in the benchmark calibration. We set $\rho=0.85$, which implies

\footnotetext{
${ }^{21}$ While the level of foreign productivity is actually lower than U.S. productivity, for simplicity we begin with a calibration in which the two economies are identical. This simplification seems reasonable, since our results for the decline in pass-through depend critically on the change in relative productivity in the two countries rather than their initial levels.
} 
an aggregate trade-price elasticity for the benchmark calibration of $2 .{ }^{22}$ The discount factor $\beta=1.03^{-0.25}$, and the utility function parameter $\chi$ is set to 1.5 , which implies a Frisch elasticity of labor supply of $2 / 3$. We set $\chi_{0}$ and $\chi_{0}^{*}$ to imply $L=L^{*}=1$ in the benchmark calibration.

For the initial levels of technology, we choose $Z=Z^{*}=1$. As discussed earlier, foreign technology rose about 40 percent relative to the level of U.S. productivity over the past 25 years. For the 2004 calibration, we choose a more conservative 35 percent increase in relative productivity by setting $Z^{*}=1.35$. Consistent with Figure 3 , we set $D=D^{*}=1.1$ in the benchmark calibration and lowered $D=D^{*}=1.05$ in the 2004 calibration.

For the fixed costs of trade we set $f_{x}=f_{x}^{*}=0.46$ which implies that the import share in the home economy is about 10 percent. Since we assume that trade is balanced in the initial steady state, the foreign economy has the same import share. We choose $\alpha_{x}=\alpha_{x}^{*}=2.5$ so that after the fall in trade costs and increase in foreign productivity the home country's import share rises about 4 percentage points.

We also compare our benchmark calibration to one with CES preferences (i.e., $\eta=0$ ). Table 2 reports the parameter values used for the CES calibration, which were selected in an analogous manner to our benchmark calibration. Table 3 shows that both the CES and benchmark calibration (by construction) match the observed volatility of output and correlation between import prices and the exchange rate in the 1980s. However, only the benchmark calibration with $\eta \neq 0$ has the flexibility to match the observed value of $\beta_{p_{m}, q}$ in the 1980 s. Although the benchmark calibration implies slightly more exchange rate volatility than the CES calibration, both versions of the model understate the amount of volatility relative to the data. Thus, while the NCES demand curves better account for the observed relationship between the relative import price and the real exchange rate, they do not by themselves explain other important aspects of the data emphasized in the international business cycle literature. ${ }^{23}$

${ }^{22}$ We define the aggregate trade-price elasticity by differentiating aggregate import demand:

$$
\omega_{t}^{*} C_{m t}=\frac{\omega_{t}^{*}}{1+\omega_{t}^{*}}\left[\frac{1}{1+\eta}\left(\frac{P_{m t}}{\Gamma_{t}}\right)^{\frac{\rho}{\gamma-\rho}}+\frac{\eta}{1+\eta}\right] C_{t}
$$

with respect to $\frac{P_{m t}}{\Gamma_{t}}$ holding $C_{t}$ and $\omega_{t}^{*}$ constant. With $\rho<1$ in our benchmark calibration, this aggregate elasticity is lower than the elasticity of demand for individual good $\mathrm{i},\left|\epsilon_{m t}(i)\right|$.

23 See Bergin and Feenstra (2001) for a discussion of how the interaction of NCES demand curves with sticky prices denominated in local currency can be helpful in accounting for exchange rate dynamics. 


\section{Results}

To gain intuition for our main results, we first illustrate the implications of our setup for pass-through in partial equilibrium. We then demonstrate how our preferred measure of passthrough, $\beta_{p_{m}, q}$, depends on the economy's shocks. Finally, we discuss our main findings regarding the effects of falling trade costs and higher foreign productivity on pass-through. In doing so, we pay particular attention to the influence of both the intensive and extensive trade margins.

\subsection{A Partial Equilibrium Explanation for Declining Pass-Through}

The upper left panel of Figure 5 plots our calibrated demand curve of import good $i$ and compares it to the CES demand curve. The absolute value of the demand elasticity for good $i,\left|\epsilon_{m t}(i)\right|$, is shown in the upper right panel. Our calibrated demand curve is consistent with strategic complementarity in price setting, as the absolute value of the elasticity is increasing in an exporter's relative price. Therefore, an exporter finds it optimal to reduce its markup rather than increase its prices, and, hence, direct pass-through, $\kappa_{m t}(i)$, is incomplete.

Another important implication of our demand curve is that pass-through will fall with a decline in the cost of exporting. Thus, our model will be able to account for a declining pass-through via either a fall in trade costs or a rise in foreign productivity relative to U.S. productivity. We now discuss the intuition for this result.

We begin by noting that foreign exporter $i$ 's marginal revenue satisfies:

$$
M R_{m t}(i)=\frac{P_{m t}(i)}{\mu_{m t}(i)}=P_{m t}(i)\left[1-\frac{1}{\left|\epsilon_{m t}(i)\right|}\right] \text {. }
$$

The lower left panel of Figure 5 displays marginal revenue (in logs and scaled by $\Gamma_{t}$ ) as a function of the relative price $\frac{P_{m t}(i)}{\Gamma_{t}}$. As a firm increases its price relative to the price of its competitors, marginal revenue exhibits diminishing returns. At a low relative price, the demand elasticity is also low and an increase in exporter $i$ 's relative price boosts marginal revenue because of a) the direct effect of the rise in the firm's price and b) the increase in the demand elasticity as an exporter's price rises relative to its competitors. However, as the exporter's relative price increases and the demand elasticity becomes high enough, the latter effect becomes negligible and the increase in marginal revenue is limited to only the direct effect of the increase in price. (As the demand elasticity approaches infinity, a firm is essentially setting its price equal to marginal cost.) Thus, the effect of strategic complementarity in price setting diminishes as the 
elasticity rises, and, as displayed in the lower right panel of Figure 5, an exporter's markup is more responsive to $\frac{P_{m t}(i)}{\Gamma_{t}}$ at a low elasticity (i.e., high markup) and less responsive to $\frac{P_{m t}(i)}{\Gamma_{t}}$ at a high elasticity (i.e., low markup).

A consequence of the concavity of the marginal revenue schedule is that a fall in an exporter's costs will result in a decline in direct pass-through. To illustrate this point, consider the dashed blue line, labelled $m c_{H}$, of the lower left panel, which shows the logarithm of the exporter's marginal cost denominated in domestic currency units (also scaled by $\Gamma_{t}$ ). At this portion of the marginal revenue schedule, a real (exogenous) depreciation of the domestic currency that results in a 3 percent increase in firm $i$ 's marginal cost $\left(m c_{H}^{\prime}\right)$ only results in about a 1 percent increase in a firm's relative price, so that direct pass-through is roughly 33 percent. Now, suppose a fall in trade costs shifts the firm's marginal costs down to $m c_{L}$. In this case, a 3 percent real depreciation of the domestic currency increases the exporter's costs from $m c_{L}$ to $m c_{L}^{\prime}$ and results in only about a 0.45 percent increase in relative price, so that direct pass-through is roughly 15 percent. Pass through is lower for a low-cost producer because a cost increase requires a smaller increase in price, since the associated rise in the demand elasticity provides an extra boost to marginal revenue.

In comparison, under CES demand curves direct pass-through of exchange-rate changes will be complete: A two percent home currency depreciation results in a two percent increase in price regardless of an exporter's costs. This reflects the fact that the demand elasticity, and thus the markup, do not vary with a monopolist's relative price.

\subsection{The Effects of Different Shocks on Pass-Through}

We now show that productivity and trade-cost shocks have different effects on our two measures of pass-through. An important difference between the two measures is that $\kappa_{m}$ is independent of the economy's iid shocks, while $\beta_{p_{m}, q}$ is not. To illustrate this, the second column of Table 4 shows the effects of a one standard deviation increase in home technology for the benchmark calibration. Home technology shocks induce a real depreciation of the home currency (i.e., a rise in $q_{t}$ ) and put upward pressure on the real marginal cost of foreign firms, as foreign labor supply contracts and real wages rise abroad. Import prices at home increase, though by less than the rise in $q_{t}$, since foreign exporters react by lowering their markups. Accordingly, our measure of pass-through, $\beta_{p_{m}, q}$, will be positive following a technology shock, as import prices rise with the real exchange rate.

The implications of a change in trade costs on pass-through differ substantially from 
those triggered by changes in technology. The third column of the table shows that following an increase in the foreign exporter's per-unit cost $D_{t}^{*}$ pass-through will be negative: because of the fall in the demand for foreign goods, the increase in foreign trade costs leads to an appreciation of the domestic currency, while import prices simultaneously rise as the cost of exporting increases. Note that import prices do not rise as much as the increase in foreign real marginal costs since foreign exporters decide to lower their markups.

Overall, our calibration procedure implies that the bulk of the variation in the real exchange rate and the relative import price are driven primarily by technology shocks. As a consequence, the values of $\beta_{p_{m}, q}$ reported in Table 3 for the benchmark calibration mainly reflect the influence of technology shocks. ${ }^{24}$

\subsection{Trade Integration and Declining Pass-Through}

Table 5 shows the effects of lowering trade costs and higher foreign productivity on pass-through and important steady state prices and quantities. The table shows the value of the variables in steady state except for $\beta_{p_{m}, q}$, which is obtained from log-linearizing the model and computing the population moments of the model's variables given the shock processes. We start by looking at the effects of changing one variable at a time (columns 2, 3 and 5), before analyzing their combined impacts (last column). As shown in the second column, a five percentage point fall in the trade costs of foreign exporters reduces the real marginal cost of exporting (denominated in terms of the home consumption bundle) by 3.5 percent. Note that the fall in foreign exporters' real marginal cost, $q D^{*} \frac{w^{*}}{Z^{*}}$, is less than the decline in $D^{*}$ as increased demand for the foreign good puts upward pressure on the real exchange rate, $q$, and on foreign wages. With lower costs, foreign exporters reduce their prices and the home country's import share rises 0.7 percentage point. Because foreign exporters' prices fall relative to their competitors - the domestic firms, they are able to increase their markups and still gain market share. Conversely, the prices for domestic goods rise relative to their competitors, and domestic firms are forced to cut their markups in reaction to stiffer competition from abroad.

With higher markups on foreign goods, the strategic complementarity intensifies and foreign exporters become more willing to vary their markups in response to cost shocks (see the lower left panel of Figure 5). Thus, the 5 percentage point decline in trade costs causes the

\footnotetext{
${ }^{24}$ It is interesting to note that the cyclicality of the domestic producers' markups in the home market depends on the source of the shock. Domestic markups are countercyclical conditional on changes in trade costs faced by home exporters and procyclical with respect to the other shocks. The domestic markup is procyclical unconditionally, reflecting the importance of technology shocks. Incorporating nominal rigidities in domestic prices would imply a countercyclical markup.
} 
direct pass-through measure $\kappa_{m}$ to fall from 0.48 to 0.462 , or 1.8 percentage points. This fall in $\kappa_{m}$ also leads to a reduction in our statistical measure of pass-through, $\beta_{p_{m}, q}$, of 2.3 percentage points. To understand the fall in $\beta_{p_{m}, q}$, recall that equation (28, reproduced below) implies a fall in $\kappa_{m}$ directly lowers $\beta_{p_{m}, q}$ :

$$
\beta_{p_{m}, q}=\kappa_{m}+\kappa_{m}\left[\frac{\operatorname{cov}\left(\Delta\left(\hat{w}_{t}^{*}-\hat{Z}_{t}^{*}\right), \Delta \hat{q}_{t}\right)}{\operatorname{var}\left(\Delta \hat{q}_{t}\right)}+\frac{\operatorname{cov}\left(\Delta \hat{D}_{t}^{*}, \Delta \hat{q}_{t}\right)}{\operatorname{var}\left(\Delta \hat{q}_{t}\right)}\right]+\left(1-\kappa_{m}\right)\left[\frac{\operatorname{cov}\left(\Delta \hat{\xi}_{t}, \Delta \hat{q}_{t}\right)}{\operatorname{var}\left(\Delta \hat{q}_{t}\right)}\right]
$$

Moreover, the decline in $\kappa_{m}$ implies that there is less weight on the marginal cost term (the first term in square brackets) and more weight on the price competitiveness term (the second term in square brackets). The marginal cost term is larger than the price competitiveness term because $\xi_{t}$ has little variation (See Table 4). As a result, a fall in $\kappa_{m}$, by shifting a firm's emphasis in pricing away from cost considerations to considerations of price competitiveness, induces an even larger decline in $\beta_{p_{m}, q}$.

A fall in $D$, the trade cost on domestic goods sold to the foreign economy, also lowers passthrough (third column of Table 5). In general equilibrium, increased foreign demand for home goods causes an appreciation of the home currency that reduces the cost of foreign exporters and leads to a fall in pass-through. The appreciation of the currency results in the real cost of foreign exporters (in home currency) falling by 0.7 percent. This decline in costs triggers a fall in foreign exporters' prices relative to prices of domestic goods in the home market. As a result, exporters increase their markups and prices of foreign goods decline only 0.3 percent. At these higher markups, $\kappa_{m}$ declines 0.4 percentage point and $\beta_{p_{m}, q}$ declines 0.6 percentage points.

For simplicity, we calibrated the fall in $D$ and $D^{*}$ based on transport costs and tariffs for U.S. imports. We view this approach as conservative, since tariff data from the United Nations Conference on Trade and Development (UNCTAD) indicates that import tariffs outside the United States and especially in developing countries have fallen more than in the United States. If we took the UNCTAD data into account, the fall in an exporter's costs would be larger, inducing a more pronounced decline in pass-through.

The fourth column of Table 5 shows the combined effects of lowering trade costs in the home and foreign economies. In this case, foreign exporters' share of the domestic market expands by 0.9 percentage point and our statistical measure of pass-through declines about 3 percentage points.

The fifth column of Table 5 displays the effects of raising the level of foreign productivity 
by 35 percent. Although there is a substantial increase in foreign real wages in response to the higher level of productivity, marginal costs in foreign currency fall. The foreign currency also depreciates; so, an exporter's marginal cost in home currency units falls almost 19 percent. This large decline in foreign costs allows foreign exporters to both substantially reduce prices and expand their markups at the expense of their domestic competitors. Consequently, the decline in $\beta_{p_{m}, q}$ is a sizeable 12.5 percentage points.

The last column of Table 5 displays the decline in pass-through from the benchmark calibration to 2004 calibration in which the increase in foreign productivity is combined with the decline in $D$ and $D^{*}$. Higher productivity and lower trade costs have a substantial impact on pass-through. Overall, $\beta_{p_{m}, q}$ falls almost 15 percentage points, which accounts for about one third of the observed decline. The fall in pass-through occurs even though the home market is simultaneously becoming more competitive: markups on domestic goods fall 1.7 percentage points (see Table 2 for a more detailed comparison of the properties of the benchmark and 2004 calibrations). These results broadly capture the view that pass-through has fallen in the United States because of increased foreign competition, which in turn has reduced profit margins of domestic producers in the U.S. market.

The positive relationship between trade costs and pass-through emphasized in our model is broadly in line with U.S. industry-level data since the early 1980s. Figure 6 relates the changes in industry-specific pass-through (reported in Section 2) to the changes in industryspecific trade cost (discussed in Section 3). The figure indicates that declines in trade costs are correlated with declines in pass-through. As indicated by the solid line, a 1 percentage point decline in trade costs is associated with a 0.7 percentage point decline in pass-through, about the same magnitude as in our benchmark calibration. This estimate is based on data from both 2- and 3-digit industries. Estimation using only the more disaggregated industries implies a slope coefficient of 2.3 (the dashed line).

Although the model is able to explain a significant part of the decline in pass-through, it does not account for the observed decline in the correlation between import prices and the exchange rate. As shown in Table $3, \beta_{p_{m}, q}$ has declined due to both falls in the relative volatility of import prices and the correlation of import prices with the exchange rate. In comparison, the model is only able to account for the decline in the relative volatility of import prices. As a result, other factors such as changes in the magnitudes and types of shocks are also important in explaining the decline in pass-through, and we leave a more thorough understanding of the reduced correlation between import prices and the exchange rate to future research.

Finally, we note that with producers engaging in price discrimination, a household might 
find it profitable to exploit deviations in the law of one price. However, we verified that in the benchmark calibration households have no incentive to do so because deviations from the law of one price (as measured by $\left|p_{d}-p_{m}^{*} q\right|$ ) are less than 10 percent, which is the cost of trading goods across countries. Deviations from the law of one price are less than the level of the trade cost, because a monopolist must take into account the influence of its competitors' prices on its own price setting behavior: in the market where its costs are low, a producer sets a high markup, while in the market where its costs are high, it sets a low markup. Thus, the strategic complementarity in price setting acts to offset deviations from the law of one price arising from the presence of trade costs.

The strategic complementarity also implies that the degree of price discrimination declines in response to a fall in trade costs. Given lower trade costs, a firm increases its markup abroad and lowers it in its own market and, as such, markups converge. These changes in markup, however, do mute the degree to which prices change in response to the fall in trade costs. For example, the 5 percentage point fall in $D$ and $D^{*}$ only results in about a 2 percentage point convergence in prices. This result is consistent with the evidence that notwithstanding an increase in trade integration, price convergence remained muted in comparison. ${ }^{25}$ In comparison, in an economy with constant markups, deviations from the law of one price would decline one-for-one with the fall in trade costs.

\subsection{The Impact of Entry on Pass-Through}

We now assess the interaction of the intensive and extensive trade margins with the strategic complementarity and their role in accounting for the decline in pass-through. To do this, we consider a version of our model that abstracts from entry altogether and then consider a version in which only foreign exporters make entry decisions. In each case, we consider a fall in domestic and foreign trade costs of 5 percentage points and an increase in foreign productivity of 35 percent.

To better understand the relative importance of the intensive and extensive margins, Figure 7 plots a number of key variables as a function of the number of foreign exporters. We do so for three different cases: the benchmark calibration with relatively high trade costs and low foreign productivity (the dashed blue line), the 2004 calibration with low trade costs and high foreign productivity (the dotted red line), and the 2004 calibration except only foreign

\footnotetext{
25 See Engel and Rogers (2004) and Bergin and Glick (2005). Bergin and Glick (2005) also report puzzling instances in which price dispersion increased over time as barriers to trade fell.
} 
exporters make entry decisions (the dashed-dotted green line). The corresponding numerical results to Figure 7 are shown in Table 6.

Consider first the dashed blue lines in each panel. As the number of foreign exporters increases, per-unit profits of export good $i$ decline due to lower demand for each individual good and a decline in an exporter's markup. This markup decline reflects that an increase in the number of foreign exporters drives up wages and production costs in the foreign economy, inducing a real home currency deprecation and a rise in the relative import price, $p_{m}$. Conversely, the markups of domestic firms in the domestic market increase.

Both measures of pass-through increase as the number of foreign exporters rises. As discussed earlier, this increase reflects that a reduction in an exporter's markup is associated with an increase in direct pass-through, $\kappa_{m}$. Also, an increase in the number of exporters in the domestic economy implies that there are more firms who change their prices in response to exchange-rate movements, which also increases pass-through in general equilibrium, $\beta_{p_{m}, q}$. Thus, as in Dornbusch (1987), our model implies that other things equal, an increase in the number of foreign exporters leads to higher pass-through of exchange rate changes to import prices. $^{26}$

Returning to the upper left panel, the equilibrium number of foreign exporters in the benchmark calibration is given by point A where per-unit profits intersect with the fixed cost (the solid black line). What happens when we lower trade costs and raise foreign productivity but completely abstract from the extensive trade margin? The equilibrium shifts from point A to point B, as the fall in export production costs raises the demand for an exporter's good as well as his profits. As shown in the upper right panel, the import share in the home economy also rises from about 10 percent to 10.7 percent. Lower production costs are also associated with an increase in the markups of foreign exporters and, as shown in the second column of Table 6, a decline in pass-through of about 15.1 percentage points. Consequently, most of the decline in pass-through occurs along the intensive trade margin.

Now consider the case in which we allow for the entry of foreign exporters in response to the decline in the cost of exporting. In this case, the equilibrium shifts from point B to point $\mathrm{C}$, as the increase in profits induces more exporters to pay their fixed entry cost. Accordingly,

\footnotetext{
${ }^{26}$ Our model implies that the import share gained through the intensive margin lowers pass-through, whereas import share gained through the extensive margin increases pass-through. These two effects may help explain the empirical results of Feenstra, Gagnon, and Knetter (1996) for automotive exporters. At low levels of market share, they estimate that pass-through declines as market share increases. Whereas, for a high market share, pass-through rises with an increase in market share. See Alessandria (2004) for an alternative theoretical analysis based on search costs that can also account for the observed U-shaped relationship between market share and pass-through.
} 
the import share now rises to about 14.6 percent and there is some decline in the markups of foreign exporters. While the two measures of pass-through rise, the effect is small relative to the decline in pass-through associated with the intensive margin.

When we further endogenize home exporters' entry decisions, the equilibrium moves from point $\mathrm{C}$ to point $\mathrm{D}$, which corresponds to the last column in Table 6 . Since foreign firms are 35 percent more productive than in the initial equilibrium (point A), foreign demand for domestic goods falls and domestic exporters decide to exit the foreign market. Table 6 shows that this reduction in the number of domestic exporters implies a smaller appreciation of the domestic real exchange rate and as a result the profit and markup functions for a foreign exporter shifts down to the red dotted line. At equilibrium point $\mathrm{D}$, foreign exporters markups are smaller and, in turn, the direct measure of pass-through, $\kappa_{m}$, is higher than at point C. Despite this increase in $\kappa_{m}, \beta_{p_{m}, q}$ falls, reflecting that there is less co-movement between the real exchange rate and foreign marginal cost (see equation (28)) with a decline in the number of domestic exporters in the foreign economy.

Overall, we conclude that ceteris paribus a rise in the number of foreign exporters raises pass-through. However, this effect is small relative to the decline in pass-through that results from strategic complementarity along the intensive margin in response to factors that increase trade integration.

\section{Conclusion}

In this paper, we proposed a new explanation for the decline in exchange-rate pass-through to import prices that emphasized the role of trade integration and strategic complementarity. When firms face strategic complementarity in setting prices, a fall in exporters' marginal costs may lower pass-through. Using conservative estimates of declines in per-unit trade costs and increases in foreign productivity, we show that this mechanism is able to account for about one third of the observed decline in pass-through.

To isolate and emphasize the role of strategic complementarity in price setting, we abstracted from another feature that may also lead to a decline in pass-through in response to greater trade integration. Increasing trade in intermediate goods could also lower the responsiveness of import prices to exchange rate fluctuations. In our model, introducing imported intermediate goods should reinforce the effect of trade integration on pass-through, as declining export costs increases their demand. We leave the exploration of this issue to future research. 


\section{References}

Alessandria, G. (2004). International deviations from the law of on price: the role of search frictions and market share. International Economic Review 45, 1263-91.

Alessandria, G. and H. Choi (2006). Do sunk costs of exporting matter for net export dynamics? mimeo, Federal Reserve Bank of Philadelphia.

Atkeson, A. and A. Burstein (2005). Trade costs, pricing to market, and international relative prices. mimeo, University of California at Los Angeles.

Baier, S. L. and J. H. Bergstrand (2001). The growth of world trade: Tariffs, transport costs, and income similarity. Journal of International Economics 53, 1-27.

Bergin, P. R. and R. C. Feenstra (2001). Pricing-to-market, staggered contracts, and real exchange rate persistence. Journal of International Economics 54, 333-59.

Bergin, P. R. and R. Glick (2005). Tradability, productivity, and understanding international economic integration. National Bureau of Economic Research Working Paper 11637.

Bernard, A. B., J. Eaton, J. B. Jensen, and S. Kortum (2003). Plants and productivity in international trade. American Economic Review 93, 1668-90.

Bernard, A. B., J. B. Jensen, and P. K. Schott (2003). Falling trade costs, heterogeneous firms, and industry dynamics. National Bureau of Economic Research Working Paper 9639.

Berthelon, M. and C. Freund (2004). On the conservation of distance in international trade. World Bank Policy Research Working Paper 3293.

Bodnar, G. M., B. Dumas, and R. D. Marston (2002). Pass through and exposure. Journal of Finance 5\%, 199-231.

Brun, J.-F., C. Carrere, P. Guillaumont, and J. de Melo (2005). Has distance died? evidence from a panel gravity model. World Bank Economic Review 19, 99-120.

Campa, J. M. and L. S. Goldberg (2004). Exchange rate pass-through into import prices. Centre for Economic Policy Research Discussion Papers 4391.

Chen, N., J. Imbs, and A. Scott (2004). Competition, globalization and the decline of inflation. Centre for Economic Policy Research Discussion Papers 4695.

Coe, D. T., A. Subramanian, N. T. Tamirisa, and R. Bhavnani (2002). The missing globalization puzzle. International Monetary Fund Working Paper 02/171.

Corsetti, G. and L. Dedola (2005). A macroeconomic model of international price discrimination. Journal of International Economics 67, 129-155.

Corsetti, G., L. Dedola, and S. Leduc (2005). Dsge models of high exchange-rate volatility and low pass-through. Board of Governors of the Federal Reserve System International Finance Discussion Papers 845. 
Corsetti, G. and P. Pesenti (2005). International dimensions of optimal monetary policy. Journal of Monetary Economics 52, 281-305.

Devereux, M. B. and C. Engel (2003). Monetary policy in the open economy revisited: Price setting and exchange rate flexibility. Review of Economic Studies 70, 765-783.

Dornbusch, R. (1987). Exchange rates and prices. American Economic Review 77, 93-106.

Dotsey, M. and R. G. King (2005). Implications of state-dependent pricing for dynamic macroeconomic models. Journal of Monetary Economics 52, 213-42.

Eichenbaum, M. and J. D. M. Fisher (2004). Evaluating the calvo model of sticky prices. National Bureau of Economic Research Working Paper 10617.

Engel, C. and J. H. Rogers (2004). European product market integration after the euro. Economic Policy 39, 347-84.

Feenstra, R. C. (1996). U.s. imports 1972-1994: Data and concordances. National Bureau of Economic Research Working Paper 5515.

Feenstra, R. C., J. E. Gagnon, and M. M. Knetter (1996). Market share and exchange rate pass-through in world automobile trade. Journal of International Economics 40, 187-207.

Feenstra, R. C., J. Romalis, and P. Schott (2002). U.s. imports, exports and tariff data, 1989-2001. National Bureau of Economic Research Working Paper 9387.

Frankel, J. A. (1997). Regional Trading Blocs in the World Economic System. Washington, D.C.: Institute for International Economics.

Ghironi, F. and M. J. Melitz (2005). International trade and macroeconomic dynamics with heterogeneous firms. Quarterly Journal of Economics 120, 865-915.

Goldberg, P. K. and M. M. Knetter (1997). Goods prices and exchange rates: What have we learned? Journal of Economic Literature 35, 1243-72.

Gust, C. and N. Sheets (2006). The adjustment of global external imbalances: Does partial exchange rate pass-through to trade prices matter? Board of Governors of the Federal Reserve System International Finance Discussion Papers 850.

Ihrig, J. E., M. Marazzi, and A. D. Rothenberg (2006). Exchange-rate pass-through in the g-7 countries. Board of Governors of the Federal Reserve System International Finance Discussion Papers 851.

Kimball, M. S. (1995). The quantitative analytics of the noemonetarist model. Journal of Money, Credit, and Banking 27, 1241-77.

Marazzi, M., N. Sheets, and R. J. Vigfusson (2005). Exchange rate pass-through to u.s. import prices: Some new evidence. Board of Governors of the Federal Reserve System International Finance Discussion Papers 833.

Melitz, M. J. (2003). The impact of trade on intra-industry reallocations and aggregate industry productivity. Econometrica 71, 1695-1725. 
Olivei, G. P. (2002). Exchange rates and the prices of manufacturing products imported into the united states. Federal Reserve Bank of Boston New England Economic Review 0, $3-18$.

Otani, A., S. Shiratsuka, and T. Shirota (2003). The decline in the exchange rate passthrough: Evidence from japanese import prices. Monetary and Economic Studies 21, $53-81$.

Peltzman, S. (2000). Prices rise faster than they fall. Journal of Political Economy 108, 466-502.

Rauch, J. E. (1999). Networks versus markets in international trade. Journal of International Economics 48, 7-35.

Woodford, M. (2003). Interest $\&$ Prices: Foundations of a Theory of Monetary Policy. Princeton: Princeton University Press. 


\section{Data Appendix}

\section{A Trade costs}

We use product-level (ten-digit harmonized system) U.S. import data from U.S. customs' reports to compute a measure of trade costs. We respectively measure transport costs and tariffs using the shares of freight and insurance expenditure, $F$, and collected duty, $T$, in terms of customs value of the goods, $V$, which is the value on which duties are assessed in the United States. Freight expenditure represents Feenstra, Romalis, and Schott (2002)'s measure of Import Charges: "...the aggregate cost of all freight, insurance and other charges (excluding import duties) incurred in bringing the merchandise from alongside the carrier at the port of exportation and placing it alongside the carrier at the first port of entry in the United States."In turn, customs values reflects "...the value of imports as appraised by the U.S. Customs Service. This value is generally defined as the price actually paid or payable for merchandise when sold for exportation to the United States, excluding U.S. import duties, freight, insurance and other charges incurred in bringing the merchandise to the United States."

For each available finished-goods industry (starting at the four-digit SITC level), we follow Bernard, Jensen, and Schott (2003) and compute industry-level trade costs, $d_{i t}$, as:

$$
d_{i t}=\frac{T_{i t}+F_{i t}}{V_{i t}}
$$

from 1980 to 2001. We then compute an average trade cost measure, $d_{t}$, by weighting an industry's trade cost measure by that industry's share of total customs value of finished goods:

$$
d_{t}=\sum_{i=1}^{N} \frac{V_{i t}}{\left(\sum_{j=1}^{N} V_{j t}\right)} d_{i t}
$$

where $N$ is the total number of finished-goods industries.

\section{B Trade Prices}

We report results for two different (but related) kinds of trade price indexes. First, we constructed the price index of finished goods as the chain-weighted price deflator constructed for imports of capital goods excluding computers and semiconductors, automotive products and consumer goods. The underlying data comes from the National Income and Product Accounts as reported by the Bureau of Economic Analysis. The price index for consumer goods is likewise based on a chain-weighted aggregation over the NIPA categories of consumer durables and nondurables.

We also reported results using industry-level price indexes for imports of finished goods as classified by two- and three-digit SITC code. We used two-digit industry only when the 
underlying three-digit industries' price indexes did not begin in the 1980s. These price indexes are published monthly by the Bureau of Labor Statistics. Within finished goods, we reported results for 40 industries. These 40 industries are listed in Table 7.

\section{Productivity}

The productivity indices are constructed using GDP in 1990 U.S. dollars at purchasing power parity. The data are from the Groningen Growth and Development Centre (http://www.ggdc.net). We define labor productivity based on GDP per employee rather than GDP per hour, since the former index allows for greater country coverage. This aggregate is constructed using data on Australia, Austria, Belgium, Canada, Denmark, Finland, France, Germany, Greece, Iceland, Ireland, Italy, Japan, Luxembourg, the Netherlands, New Zealand, Norway, Portugal, Spain, Sweden, Switzerland, Turkey, the United Kingdom, China, India, Indonesia, Malaysia, South Korea, Taiwan, Thailand, Argentina, Brazil, and Mexico. Note that we arrived a slightly larger productivity differential if we use GDP per hour worked and fewer countries for our foreign aggregate. 
Table 1: Volatility and Correlation of Relative Import Price and Real Exchange Rate ${ }^{a}$

\begin{tabular}{|l|c|c|c|}
\hline Moment (Differenced) & Full Sample & 1980:1-1989:4 & 1990:1-2004:4 \\
\hline $\begin{array}{l}\text { a. } \beta_{p_{m}, q} \\
\quad\left(\mathrm{a}=\mathrm{b}^{*} \mathrm{c}\right)\end{array}$ & 0.35 & 0.55 & 0.13 \\
b. $\sigma_{p_{m}} / \sigma_{q}$ & 0.47 & 0.60 & 0.25 \\
c. $\operatorname{corr}\left(q, p_{m}\right)$ & 0.75 & 0.92 & 0.51 \\
\hline Moment $($ HP-Filtered) & & & \\
\hline a. $\beta_{p_{m}, q}$ & 0.46 & 0.59 & 0.17 \\
$\quad\left(\mathrm{a}=\mathrm{b}^{*} \mathrm{c}\right)$ & & & 0.29 \\
b. $\sigma_{p_{m}} / \sigma_{q}$ & 0.54 & 0.61 & 0.60 \\
c. $\operatorname{corr}\left(q, p_{m}\right)$ & 0.85 & 0.95 & \\
\hline
\end{tabular}

${ }^{a} \beta_{p_{m}, q}$ denotes the regression coefficient from a univariate least squares regression of the real exchange rate on the relative import price. Differenced refers to data that has been log-differenced. HP-filtered series were computed by transforming the log of the variables (with $\lambda=1600$ ). 
Table 2: Parameter Values and Properties of Calibrated Models

\begin{tabular}{|l|c|c|c|}
\hline & \multicolumn{2}{|c|}{ NCES Demand } & \\
\hline & Benchmark Calibration & 2004 Calibration & CES Calibration \\
$\eta$ & 0.85 & 0.85 & 1.7 \\
$\gamma$ & -3.05 & -3.05 & 0 \\
$\beta$ & 1.1 & 1.1 & 0.835 \\
$\chi$ & 0.9926 & 0.9926 & 0.9926 \\
$\chi_{0}$ & 1.5 & 1.5 & 1.5 \\
$D=D^{*}$ & 0.79 & 0.79 & 0.83 \\
$Z$ & 1.1 & 1.05 & 1.1 \\
$Z^{*}$ & 1 & 1 & 1 \\
$f_{x}$ & 1 & 1.35 & 1 \\
$\alpha_{x}$ & 0.46 & 0.46 & 0.37 \\
$\sigma_{Z}=\sigma_{Z}^{*}$ & 2.5 & 2.5 & 2.5 \\
$\sigma_{D}=\sigma_{D}^{*}$ & 0.0178 & 0.0178 & 0.0191 \\
Home Trade Share & 0.0094 & 0.0094 & 0.008 \\
Home Firms' Domestic Markup $\left(\mu_{d}\right)$ & $10.0 \%$ & $14.0 \%$ & $10.0 \%$ \\
Foreign Exporters' Markup $\left(\mu_{m}\right)$ & 1.27 & 1.24 & 1.20 \\
Home Trade-Price Elasticity & 1.20 & 1.38 & 1.20 \\
Direct Pass-Through $\left(\kappa_{m}\right)$ & -2.0 & -1.2 & -2.0 \\
\hline
\end{tabular}


Table 3: Selected Moments of Data and Calibrated Models ${ }^{a}$

\begin{tabular}{|l|c|c|c|c|c|}
\hline \multirow{2}{*}{ Moment } & \multicolumn{2}{|c|}{ Data } & \multicolumn{3}{c|}{ Model } \\
\cline { 2 - 6 } & $1980-1989$ & $1990-2004$ & $\begin{array}{c}\text { Benchmark } \\
\text { Calibration }\end{array}$ & $\begin{array}{c}2004 \\
\text { Calibration }\end{array}$ & $\begin{array}{c}\text { CES } \\
\text { Calibration }\end{array}$ \\
\hline a. $\beta_{p_{m}, q}=\operatorname{cov}\left(\Delta q, \Delta p_{m}\right) / \operatorname{var}(\Delta q)$ & 0.55 & 0.13 & 0.55 & 0.40 & 1.08 \\
$\quad\left(\mathrm{a}=\mathrm{b}^{*} \mathrm{c}\right)$ & & & & & \\
b. $\sigma\left(\Delta p_{m}\right) / \sigma(\Delta q)$ & 0.60 & 0.25 & 0.60 & 0.43 & 1.17 \\
c. $\operatorname{corr}\left(\Delta q, \Delta p_{m}\right)$ & 0.92 & 0.51 & 0.92 & 0.92 & 0.92 \\
\hline$\sigma\left(y^{h p}\right)$ & 1.74 & 0.98 & 1.74 & 1.71 & 1.74 \\
$\sigma\left(q^{h p}\right)$ & 4.98 & 2.70 & 2.79 & 2.86 & 2.54 \\
\hline
\end{tabular}

${ }^{a}$ The subscript 'hp' denotes that a variable was transformed using the HP-filter (with $\lambda=1600$ ). 
Table 4: The Effect of iid Shocks for the Benchmark Calibration ${ }^{a}$

\begin{tabular}{|l|c|c|}
\hline \multirow{2}{*}{ Variable } & \multicolumn{2}{|c|}{ One Standard Deviation Increase in: } \\
\cline { 2 - 3 } & $\begin{array}{c}\text { Home } \\
\text { Technology }\left(Z_{t}\right)\end{array}$ & $\begin{array}{c}\text { Foreign } \\
\text { Trade Cost }\left(D_{t}^{*}\right)\end{array}$ \\
\hline Real Exchange Rate $\left(q_{t}\right)$ & 1.39 & -0.10 \\
Home Import Price $\left(p_{m t}\right)$ & 0.78 & 0.41 \\
Foreign Firm's Marginal Cost $\left(\frac{w_{t}^{*}}{Z_{t}^{*}}\right)$ & 0.23 & 0.00 \\
Competitive Price Index $\left(\xi_{t}\right)$ & 0.02 & 0.01 \\
Foreign Exporter's Markup $\left(\mu_{m t}\right)$ & -0.84 & -0.43 \\
\hline
\end{tabular}

${ }^{a}$ Entries refer to the percent change in a variable relative to its steady state value.

Table 5: The Effect of Permanently Lower Trade Costs and Higher Foreign Productivity ${ }^{a, b}$

\begin{tabular}{|l|c|c|c|c|c|}
\hline & Lower $D^{*}$ & Lower $D$ & Lower $D^{*}, D$ & Higher $Z^{*}$ & $\begin{array}{c}\text { Higher } Z^{*} \\
\text { Lower } D^{*}, D\end{array}$ \\
\hline Foreign Exporter Trade Cost $\left(D^{*}\right)$ & -5 & 0 & -5 & 0 & -5 \\
Home Exporter Trade Cost $(D)$ & 0 & -5 & -5 & 0 & -5 \\
Foreign Productivity $\left(Z^{*}\right)$ & 0 & 0 & 0 & 35 & 35 \\
Home Import Share & 0.7 & 0.2 & 0.9 & 3.3 & 4.0 \\
Home Firm Markup at Home $\left(\mu_{d}\right)$ & -0.3 & -0.1 & -0.3 & -1.4 & -1.7 \\
a. Home Import Price $\left(p_{m}\right)$ & -1.6 & -0.3 & -1.9 & -8.2 & -9.9 \\
$\quad(a=$ b+c) & 1.8 & 0.3 & & & 13.9 \\
b. Foreign Exporter's Markup $\left(\mu_{m}\right)$ & -3.5 & -0.7 & -4.1 & -19.1 & -23.8 \\
c. Foreign Marginal Cost $\left(q D^{*} \frac{w^{*}}{Z^{*}}\right)$ & 1.1 & -1.1 & 0 & -17.5 & -17.7 \\
Real Exchange Rate $(q)$ & -1.8 & -0.4 & -2.2 & -9.5 & -11.6 \\
Direct Pass-Through $\left(\kappa_{m}\right)$ & -2.3 & -0.6 & -2.9 & -12.5 & -14.7 \\
Pass-Through $\left(\beta_{p_{m}, q}\right)$ & & & & 10.9 & \\
\hline
\end{tabular}

${ }^{a}$ Entry refers to the log-difference for a variable from its value in the benchmark calibration. For the trade costs, home trade share, $\kappa_{m}$, and $\beta_{p_{m}, q}$, we report the percentage point difference. For $Z^{*}$, we report the arithmetic percentage change instead of the log-difference.

${ }^{b}$ Row a equals row b plus row c with any discrepancy due to rounding. 
Table 6: The Effect of Permanently Lower Trade Costs and Higher Foreign Productivity for Alternative Model Versions ${ }^{a, b}$

\begin{tabular}{|l|c|c|c|}
\hline & $\begin{array}{c}\text { Without } \\
\text { Entry }\end{array}$ & $\begin{array}{c}\text { With Only Foreign } \\
\text { Exporter Entry }\end{array}$ & $\begin{array}{c}\text { With } \\
\text { Entry }\end{array}$ \\
\hline Foreign Exporter Trade Cost $\left(D^{*}\right)$ & -5 & -5 & -5 \\
Home Exporter Trade Cost $(D)$ & -5 & -5 & -5 \\
Foreign Productivity $\left(Z^{*}\right)$ & 35 & 35 & 35 \\
Home Import Share & 0.7 & 4.6 & 4.0 \\
Home Firm Markup at Home $\left(\mu_{d}\right)$ & -1.7 & -1.9 & -1.7 \\
a. Home Import Price $\left(p_{m}\right)$ & -12.9 & -11.0 & -9.9 \\
$\quad(a=$ b+c) & & & \\
b. Foreign Exporter's Markup $\left(\mu_{m}\right)$ & 19.8 & 16.1 & 13.9 \\
c. Foreign Marginal Cost $\left(q D^{*} \frac{w^{*}}{Z^{*}}\right)$ & -23.7 & -19.2 & -17.7 \\
Real Exchange Rate $(q)$ & -15.2 & -13.0 & -11.6 \\
Direct Pass-Through $\left(\kappa_{m}\right)$ & -15.2 & -13.0 & -11.6 \\
Pass-Through $\left(\beta_{p_{m}, q}\right)$ & -15.1 & -13.4 & -14.7 \\
\hline
\end{tabular}

${ }^{a}$ Entry refers to the log-difference for a variable from its value in the benchmark calibration. For the trade costs, home trade share, $\kappa_{m}$, and $\beta_{p_{m}, q}$, we report the percentage point difference. For $Z^{*}$, we report the arithmetic percentage change instead of the log-difference.

${ }^{b}$ Row a equals row b plus row c with any discrepancy due to rounding. 
Table 7: Finished Goods Industries

\begin{tabular}{|l|l|}
\hline SITC & Descriptions \\
\hline 54 & Medicinal and pharmaceutical products \\
55 & Essential oils; polishing and cleansing preps \\
625 & Tires And Inner Tubes Of Rubber \\
665 & Glassware \\
666 & Pottery \\
667 & Pearls, Precious And Semiprecious Stones, Unworked Or Worked \\
716 & Rotating Electric Plants And Parts \\
721 & Agricultural Machinery (Excluding Tractors) And Parts Thereof \\
723 & Civil Engineering And Contractors' Plant And Equipment And Parts \\
724 & Textile And Leather Machinery, And Parts Thereof \\
728 & Machinery And Equipment Specialized For Particular Industries, And Parts \\
73 & Metalworking machinery \\
741 & Heating And Cooling Equipment And Parts \\
742 & Pumps For Liquids; Liquid Elevators; And Parts Thereof \\
743 & Air And Vacuum Pumps, Compressors, Fans, Centrifuges, And Filtering Apparatus \\
744 & Mechanical Handling Equipment, And Parts Thereof, N.E.S. \\
745 & Nonelectrical Machinery, Tools And Mechanical Apparatus, And Parts \\
751 & Office Machines \\
761 & Television Receivers, Including Monitors, Projectors And Receivers \\
762 & Radio Broadcast Receivers \\
763 & Sound Recorders Or Reproducers; Television Image And Sound Recorders \\
764 & Telecommunications Equipment, N.E.S.; And Parts, N.E.S., And Accessories \\
771 & Electric Power Machinery (Except Rotating Power Machinery) and Parts \\
773 & Equipment For Distributing Electricity, N.E.S. \\
774 & Electro-Diagnostic Apparatus For Medical, Surgical, Dental Or Vet. Use \\
775 & Household Type Electrical \\
778 & Electrical Machinery and Apparatus \\
781 & Motor Cars And Other Motor Vehicles Principally Designed For The Transport \\
784 & Parts And Accessories For Tractors, Motor Cars, And Other Motor Vehicles \\
81 & Prefabricated buildings; plumbing, heat and lighting fixtures \\
84 & Articles of apparel and clothing accessories \\
85 & Footwear \\
874 & Measuring, Checking, Analysing And And Controlling Instruments And Apparatus \\
881 & Photographic Apparatus And Equipment, N.E.S. \\
884 & Optical Goods, N.E.S. \\
885 & Watches And Clocks \\
893 & Articles, N.E.S. Of Plastics \\
894 & Baby Carriages, Toys, Games And Sporting Goods \\
897 & Jewelry, Goldsmiths' And Silversmiths' Wares \\
898 & Musical Instruments, Parts And Accessories Thereof; Records Tapes \\
\hline
\end{tabular}


Figure 1: The Real Exchange Rate and Relative Import Prices

Exchange Rates and Price Index in Levels

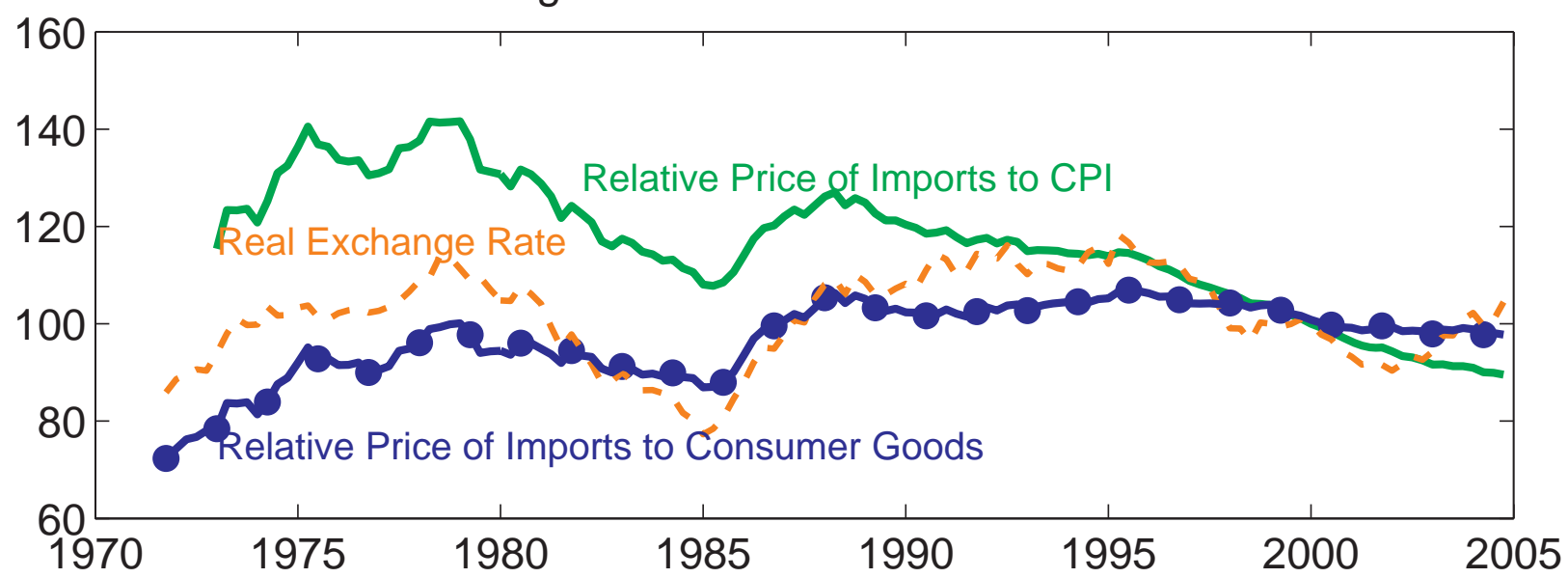

Exchange Rates and Price Index in Logged First Differences

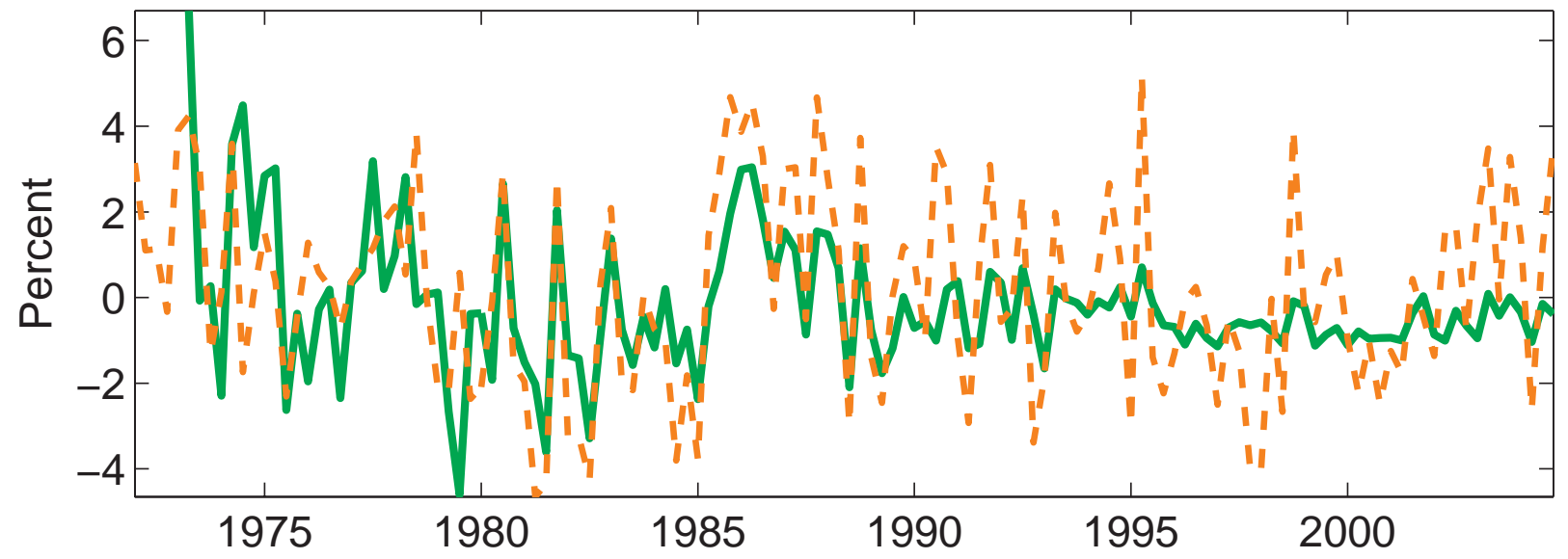

Pass-through Estimated Over a 10-year Rolling Window

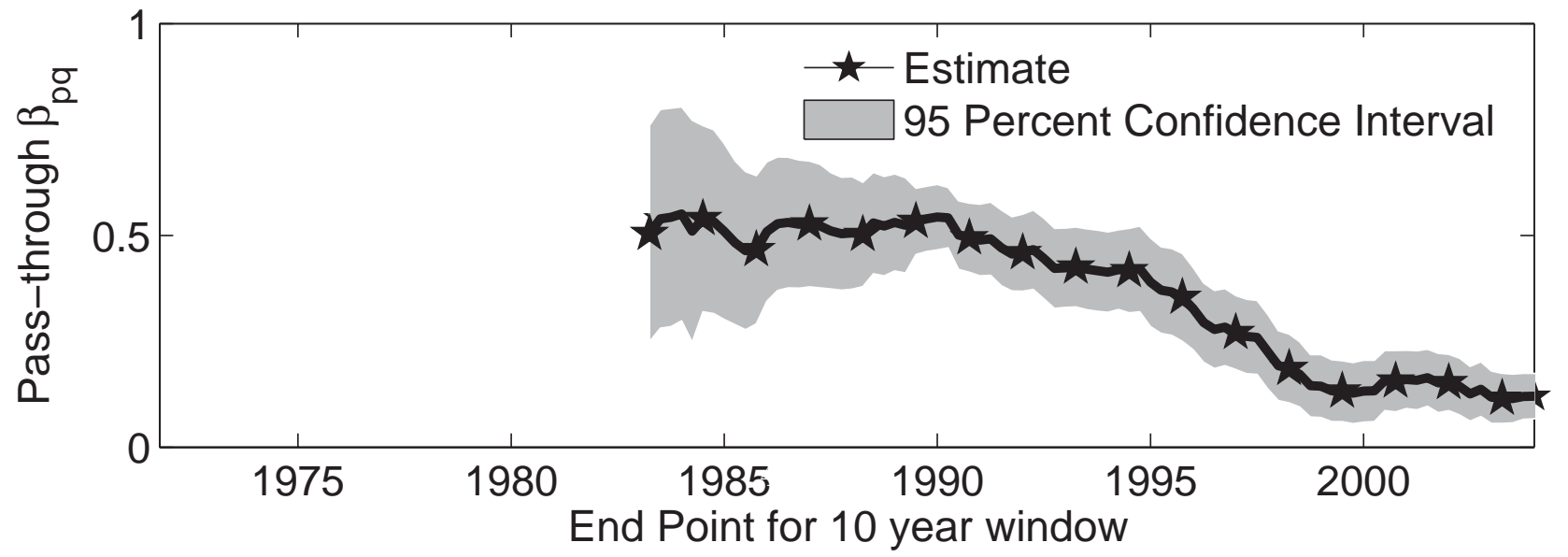


Figure 2: The Change in Pass-Through for Different Finished-Goods Industries

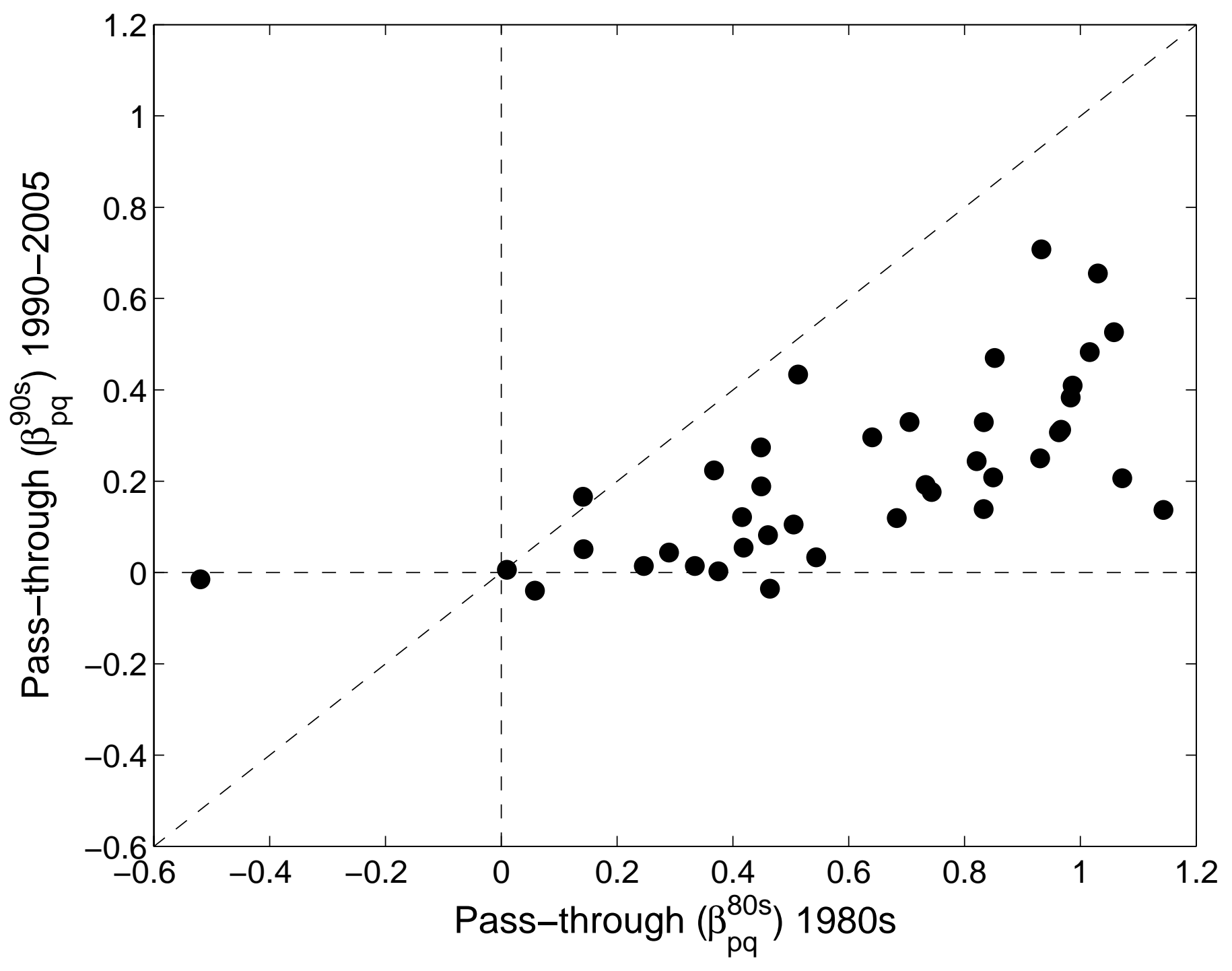


Figure 3: The Decline in Average Transport Costs and Tariffs for U.S. Imported Goods

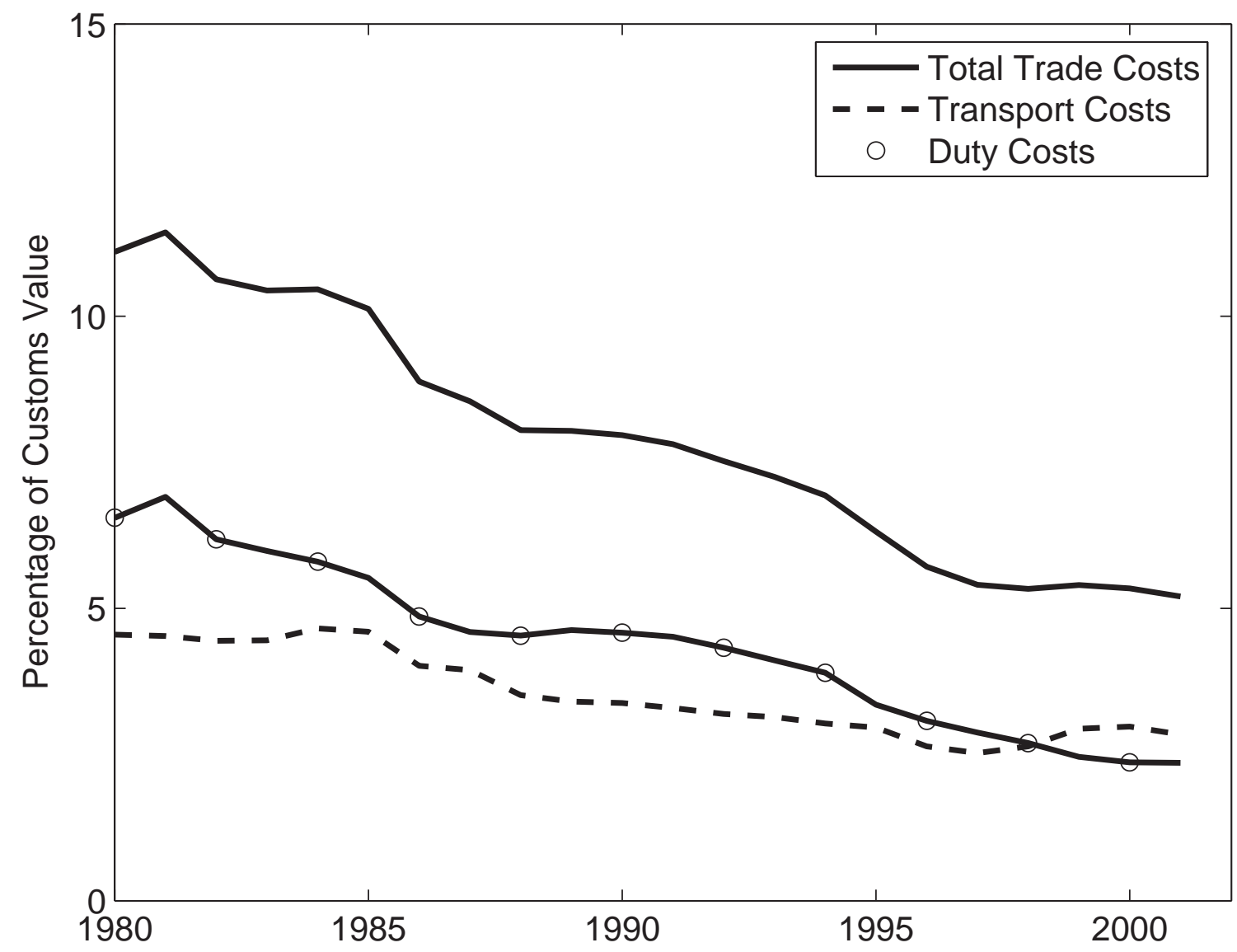


Figure 4: Growth in GDP per Employee in the United States and the Rest of the World
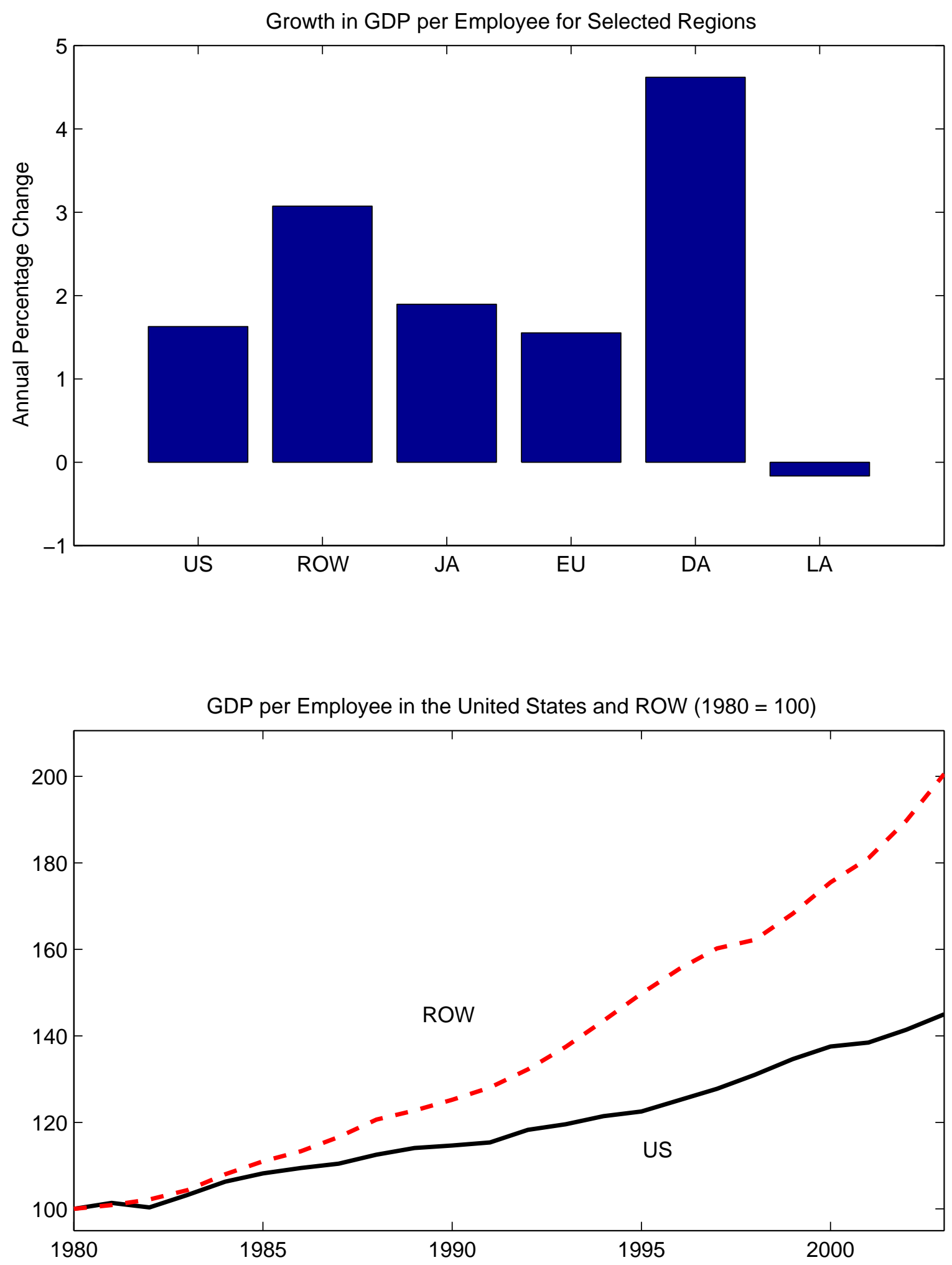
Figure 5: Import Demand and an Exporter's Marginal Revenue Schedule
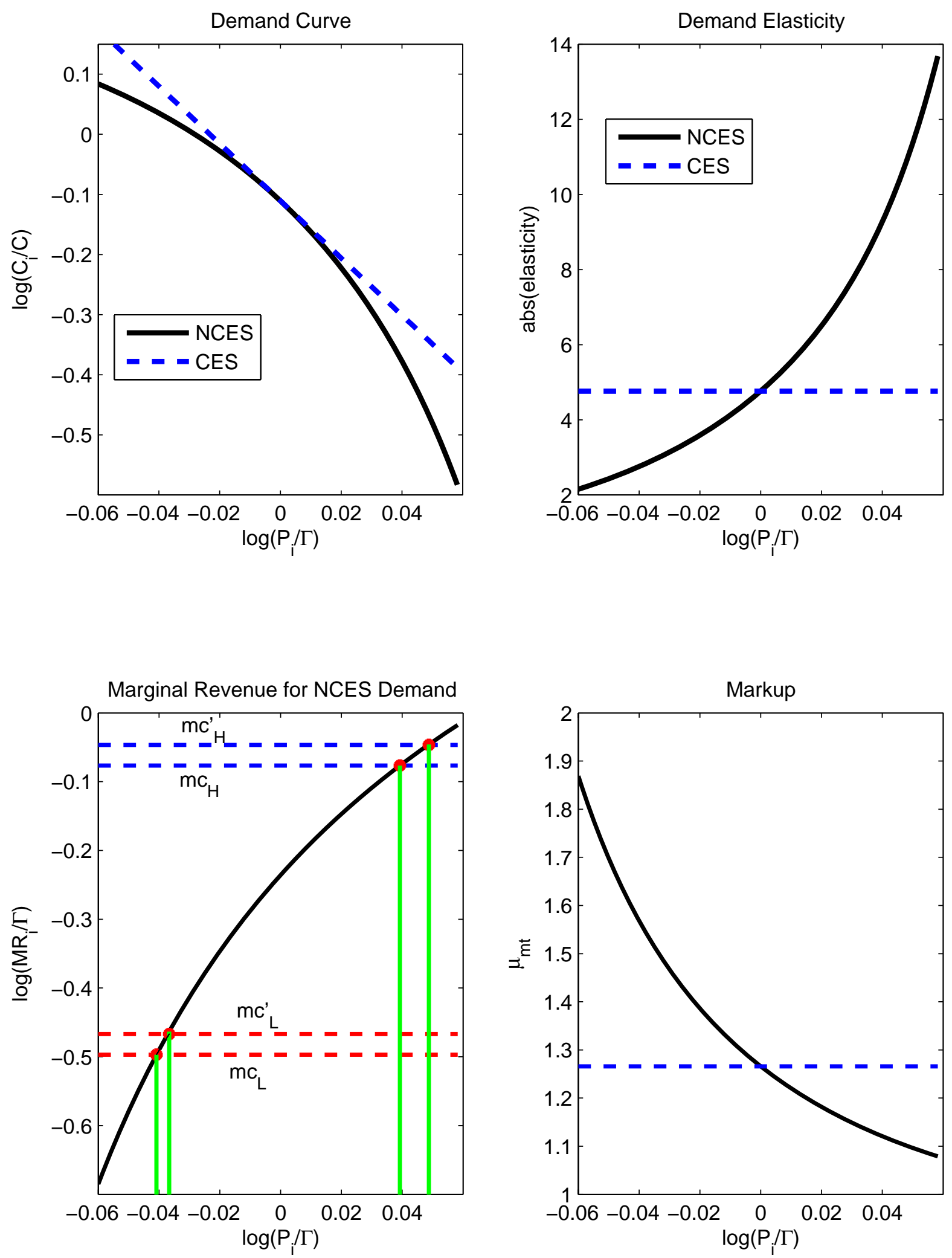
Figure 6: The Relationship Between Pass-Through and Trade Costs Based on Industry-Level Data

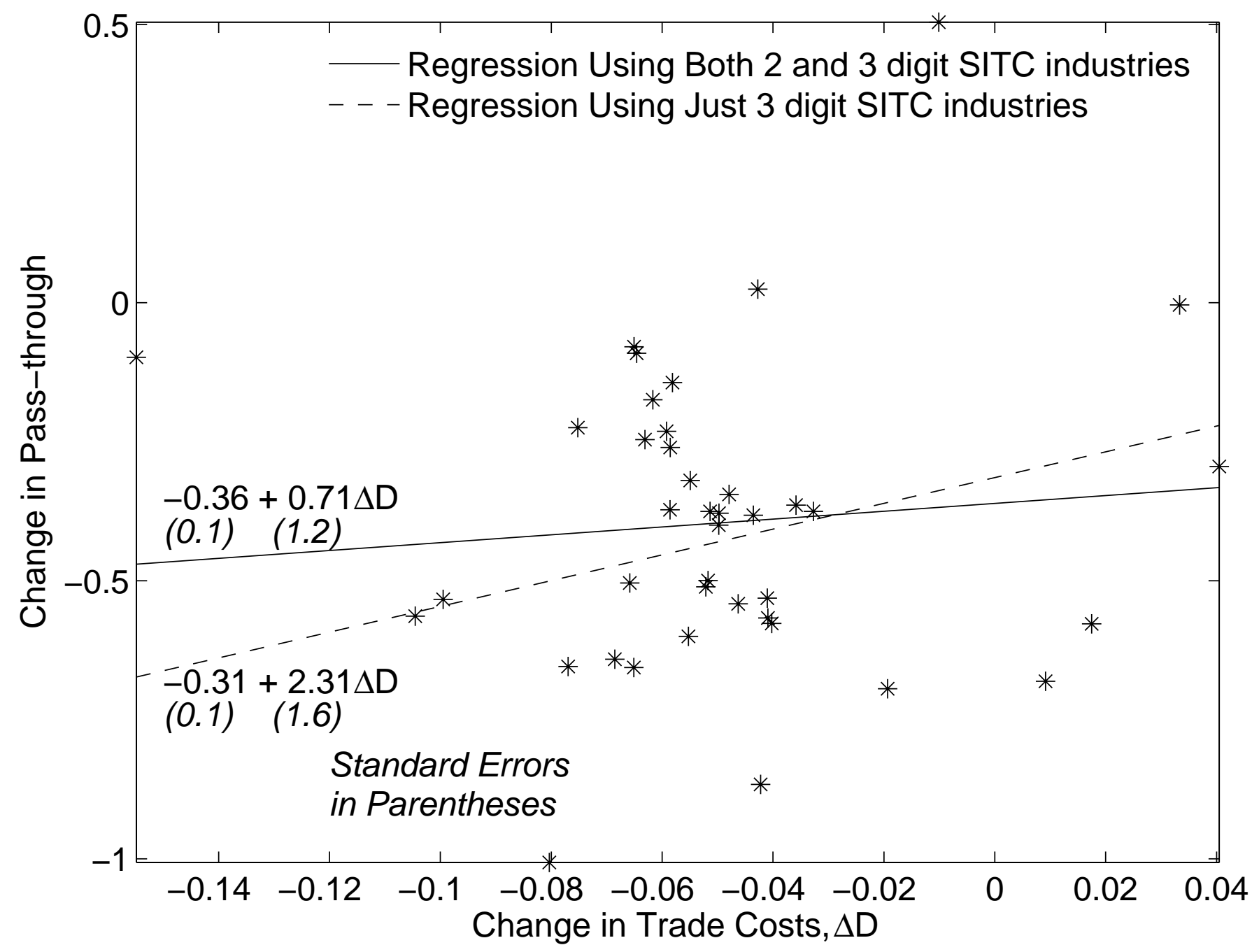


Figure 7: The Effect of the Intensive and Extensive Entry Margins on Pass-Through
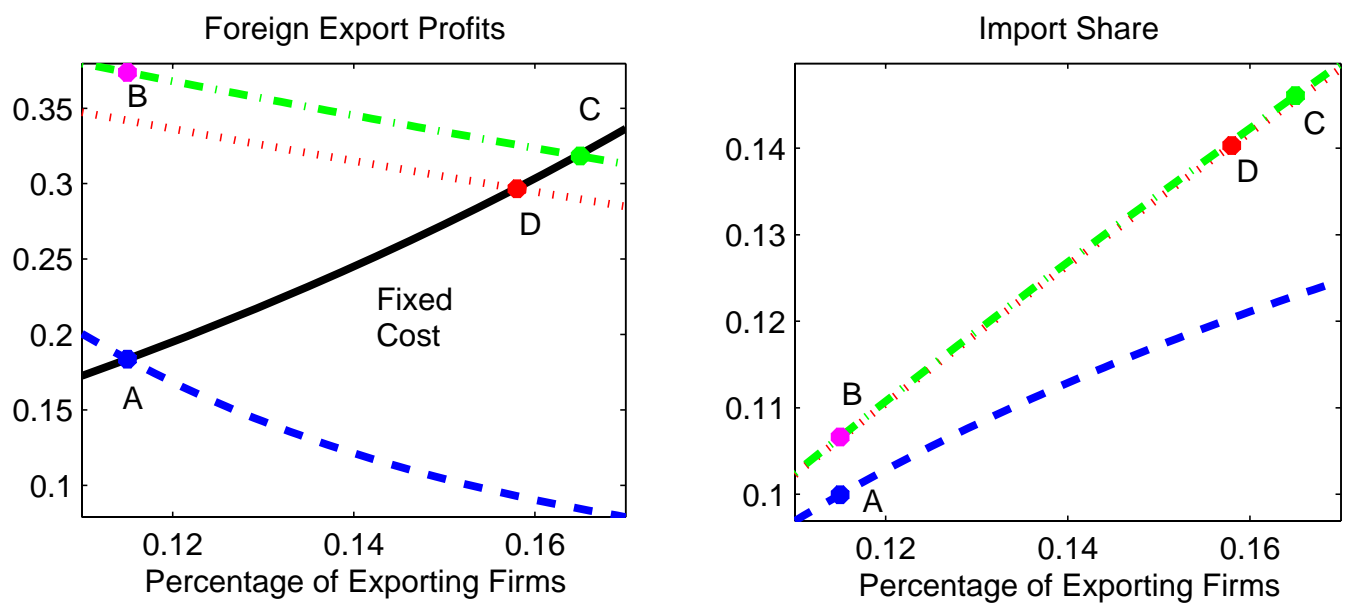

Foreign Exporter Markup
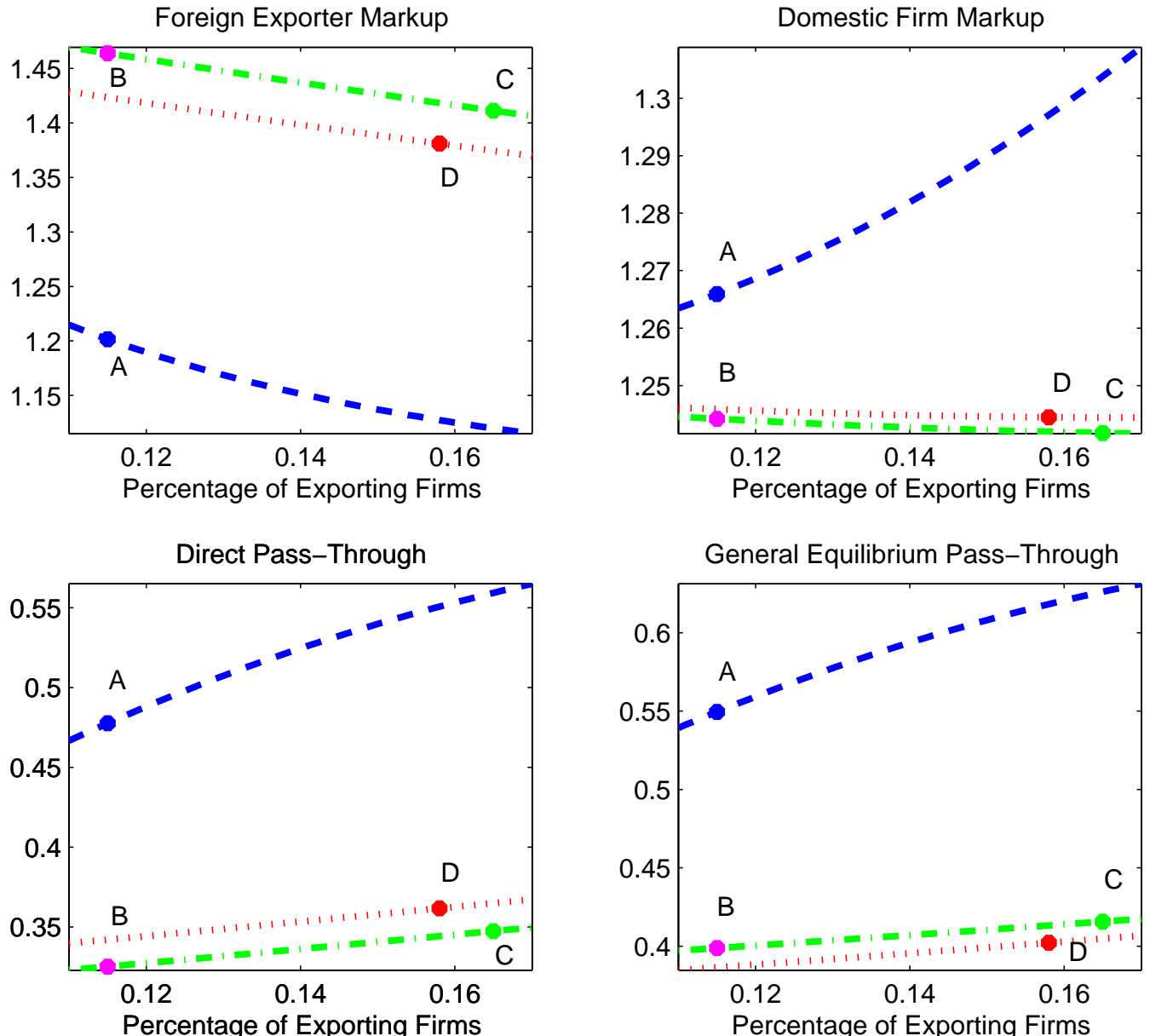

General Equilibrium Pass-Through

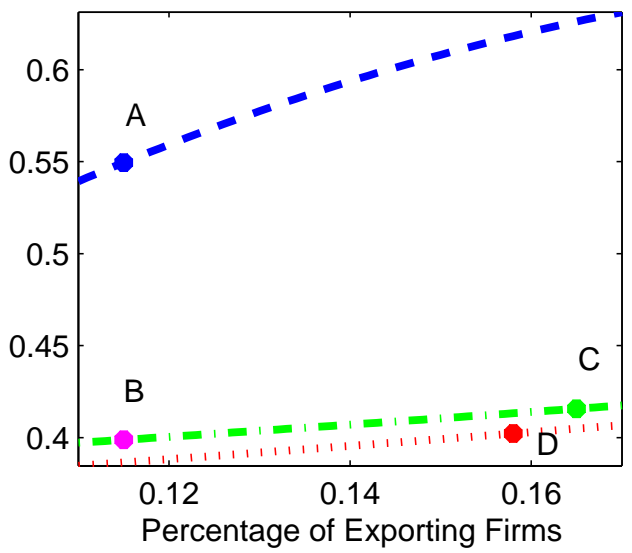

$$
\begin{aligned}
& \text { - - - Initial Values } \\
& \text { 1, } 1, \text { New Values } \\
& 1-1=\text { New Values (Only Foreign Exporter Entry) }
\end{aligned}
$$




\section{International Finance Discussion Papers}

IFDP

Number

Titles

Author(s)

2006

863

Transmission of Volatility and Trading Activity in the Global Interdealer Foreign Exchange Market: Evidence from Electronic Broking Services (EBS) Data

Fang Cai

Edward Howorka Jon Wongswan

862

What Drives Volatility Persistence in the Foreign Exchange

David Berger Market?

Alain Chaboud

Erik Hjalmarsson

Edward Howorka

861

Exchange-Rate Effects on China's Trade: An Interim Report

Jaime Marquez

John W. Schindler

860

Can the U.S. Monetary Policy Fall (Again) in an

Roc Armenter Expectation Trap?

Martin Bodenstein

859

Trade Adjustment and the Composition of Trade

Christopher Erceg

Luca Guerrieri

Christopher Gust

858

Currency Hedging and Corporate Governance: A Cross-Country Analysis

Ugur Lel

857

Modeling Direct Investment Valuation Adjustments and Estimating Quarterly Positions

Jane Ihrig Jaime Marquez

856

The U.S. Current Account Deficit and the Expected Share of World Output

Charles Engel

John H. Rogers

855

Should we Expect Significant Out-of Sample Results when Predicting Stock Returns?

Erik Hjalmarsson

854

Fully Modified Estimation with Nearly Integrated Regressors

Erik Hjalmarsson

853

New Methods for Inference in Long-Run Predictive Regressions

Erik Hjalmarsson

852

Estimation of Average Local-to-Unity Roots in Heterogenous Panels

Erik Hjalmarsson

Please address requests for copies to International Finance Discussion Papers, Publications, Stop 127, Board of Governors of the Federal Reserve System, Washington, DC 20551.

Email: publications-bog@frb.gov. Fax (202) 728-5886. 
IFDP

Number

851

850 $\underline{\text { Titles }}$

2006

Exchange-Rate Pass-Through in the G-7 Countries

The Adjustment of Global External Imbalances: Does Partial

Exchange Rate Pass-Through to Trade Prices Matter?

2005

Interest Rate Rules, Endogenous Cycles and Chaotic Dynamics in Open Economies

Fighting Against Currency Depreciation Macroeconomic Instability and Sudden Stops

The Baby Boom Predictability in House Prices and Interest Rates

Explaining the Global Pattern of Current Account Imbalances

DSGE Models of High Exchange-Rate Volatility and Low Pass-Through

The Response of Global Equity Indexes to U.S. Monetary Policy Announcements

Accounting Standards and Information: Inferences from Cross-Listed Financial Firms

Alternative Procedures for Estimating Vector Autoregressions Identified with Long-Run Restrictions

House Prices and Monetary Policy: A Cross-Country Study $\underline{\text { Author(s) }}$

Jane E. Ihrig Mario Marazzi Alexander D.

Rothenberg

Christopher Gust Nathan Sheets

Marco Airaudo

Luis-Felipe Zanna

Luis-Felipe Zanna

Robert F. Martin

Joseph W. Gruber

Steven B. Kamin

Giancarlo Corsetti

Luca Dedola

Sylvain Leduc

Jon Wongswan

John Ammer

Nathanael Clinton

Gregory P. Nini

Lawrence J Christiano Martin Eichenbaum

Robert J. Vigfusson

Alan G. Ahearne John Ammer

Brian M. Doyle

Linda S. Kole

Robert F. Martin 